\title{
CEsifo \\ WORKING

\section{Jane Beats Them All: Price Formation and Financial Returns to Investing in Rare Books}

Heinrich W. Ursprung 


\section{Impressum:}

CESifo Working Papers

ISSN 2364-1428 (electronic version)

Publisher and distributor: Munich Society for the Promotion of Economic Research - CESifo

$\mathrm{GmbH}$

The international platform of Ludwigs-Maximilians University's Center for Economic Studies and the ifo Institute

Poschingerstr. 5, 81679 Munich, Germany

Telephone +49 (0)89 2180-2740, Telefax+49 (0)89 2180-17845, email office@cesifo.de

Editor: Clemens Fuest

https://www.cesifo.org/en/wp

An electronic version of the paper may be downloaded

- from the SSRN website: www.SSRN.com

- from the RePEc website: $\quad$ www.RePEc.org

- from the CESifo website: https://www.cesifo.org/en/wp 


\title{
Jane Beats Them All: Price Formation and Financial Returns to Investing in Rare Books
}

\begin{abstract}
I report historical prices and estimate financial returns to investing in rare books. My sample consists of 25 fiction titles recommended by Clifton Fadiman in his 1960 Lifetime Reading Plan. Relying on prices realized at American and British auction houses between 1975 and 2018, I use hedonic regressions to estimate the average rate of return to each of the 25 titles. Jane Austen's novel Pride and Prejudice tops the returns to all other titles. I then construct for the entire sample of rare books price indices based on various specifications with a view to identifying the most efficient way of computing rare book price indices for larger samples of books. Estimating the financial return to investing in rare books in general, I arrive for the boom period 1975-2007 at a real rate of return of about $4.6 \%$, which exceeds similar estimates for investing in fine art. In a comparison with the returns in 1975-2007 of almost 9\% from the US stock market, investing in rare books is justified only by substantial nonpecuniary returns.
\end{abstract}

JEL-Codes: G110, Z110.

Keywords: rare books, price indices, investment in collectibles, cultural economics.

Heinrich W. Ursprung

University of Konstanz

Department of Economics

Germany - 78457 Konstanz

heinrich.ursprung@uni-konstanz.de

May 9, 2020

I thank Arye Hillman, Tommy Krieger, and Niklas Potrafke for valued comments. Helpful feedback was received from form seminar and conference participants at the 13th Dresden Workshop on Political Economy and Jadavpur University (Kolkata). 


\section{INTRODUCTION}

I examine price formation and estimate financial returns to investing in rare books. The study's objective is to complement the economic literature by exploring a hitherto neglected collectible market segment that has a rich tradition. To identify the price determinants of collectible books, I rely on hedonic regressions and a database of book auction prices covering the period 1975-2018. My sample consists of 3402 auction sales of 25 masterpieces of $18^{\text {th }}$ $20^{\text {th }}$ century English fiction selected by the renowned American intellectual, author, editor, and media personality Clifton Fadiman in his 1960 Lifetime Reading Plan. Given Fadiman's name recognition at the time, it is quite conceivable that a novice book collector in the 1970s would have chosen this selection of books to start a serious collection. Concerns about a possible selection bias are therefore unfounded. ${ }^{1}$ With few exceptions, the sample is restricted to the first editions that are much more sought-after by serious collectors than later editions. The study is exploratory. The focus is on seeking the most efficient way of constructing a rare book price index rather than on results that are representative for the financial returns of rare book collecting in general.

It is, of course, well known that in the long run financial assets have higher returns than tangible assets, especially collectibles such as fine art. The economic rationale is that collectibles yield non-pecuniary returns that need to be taken into account when assessing the overall return from an investment. Assuming rationality on the part of all market participants, the financial return differentials between traditional financial investments and investments in collectibles simply reflect the benefits that the collectors derive from ownership. Collections may provide owners with a consumption value, allow them to signal a desired social status or identity (in which case the collection could be termed an expressive investment $),{ }^{2}$ or provide the collector, even if he or she does not derive any consumption or expressive value from the collection, emotional self-gratification (the term passion investments is sometimes used to designate this motive).

Scholars in economics and finance have empirically examined the monetary returns of various types of collectibles and compared them with the returns of traditional financial assets; for a survey see Burton and Jacobsen (1999). In particular, the literature on the working of the art market is well established (Pownall et al. 2019, Renneboog and Spaenjers 2013), as

\footnotetext{
${ }^{1}$ To avoid a selection bias, I do not use the later editions of Fadiman's Lifetime Reading Plan that appeared in 1976, 1986, and 1997.

2 See Hillman (2010) for economic aspects of expressive behavior.
} 
is the wine economics literature (Ashenfelter et al. 2019, Le Fur and Outreville 2019). There are scientific studies of the markets for stamps (Dimson and Spaenjers 2011), diamonds (Scott and Yelowitz 2010, Renneboog and Spaenjers 2012), and classic cars (Martin 2018, Laurs and Renneboog 2019). Given that scholars are usually considered a rather bookish tribe, conspicuously absent from this list of collectables are, however, rare books. ${ }^{3}$ The objective of this study is to fill this gap. After all, precious books have been collector's items for at least as long as fine art (Raven 2013).

The rare book market differs in some respects from the art market. Books published since the invention of the movable-type printing press are, first, not unique items. Books are multiples, which might suggest that price indices and rates of return are best estimated using the repeat sale method. This is however not the case because prices even of the very same issue of a collectible book can vary a great deal, depending on condition and other features. Since particular copies can usually not be traced across time, the hedonic pricing approach is a superior alternative. ${ }^{4} \mathrm{~A}$ second distinguishing feature concerns supply and demand. The prices of works of fine art are affected by the death of the artist, i.e. the supplier of artwork (Ursprung and Wiermann 2011). Because books of a given author are less substitutable than the artwork of a given artist and writers become much later in their lives iconic figures than artists, this kind of supply shock is unlikely to be observed.

As far as the demand side is concerned, rare books are not suited as well as artwork to signal the buyer's social status or values; books simply cannot be presented as conspicuously as a large oil painting or even a well-placed small print by an artist whose unique style is easily recognized. Moreover, the recognition value of rare books is restricted to a small group of connoisseurs. The non-pecuniary returns of a rare book collection can thus be expected not to include substantial expressive benefits; rare book collectors are, if anything, rather passion investors (bibliomaniacs). Whether this difference between art and rare-book collectors translates into significant differences in financial returns is, of course, an empirical question.

\footnotetext{
${ }^{3}$ The working of market for new books and the appertaining regulatory constraints are analysed in Canoy et al. (2006). Kells (2003) describes the Australian Book Auction Records and suggests some research topics that could draw on book auction data. Wyburn and Roach (2012) identify with help of hedonic regressions the price determinants of American collectable comic books.

${ }^{4}$ In this respect wine and multiples (prints) in the graphic arts appear to be more homogenous. Their prices are therefore better suited to be investigated with the repeat sale method (see Burton and Jacobsen 2001 for wine and Pesando and Shum 2007, 2008 for prints). This is not to say that the price formation of prints or wine have not been explored with the help of hedonic regressions (see, for example, Faye and Le Fur 2019). On the methods of computing price indices, see Ginsburg et al. (2006).
} 
It stands, however, to reason that rare book prices are not as much driven by changes in income and wealth of high net worth individuals as art prices (Goetzmann et al. 2011), simply because high net worth individuals are, arguably, more likely to have a need for selfrepresentation than people who do not belong nor aspire to belong to the fashionable society.

The data are described in detail in the following section. The hedonic approach to explaining rare book price formation is introduced in Section 3 by way of investigating the price determinants and the price development of the 1922 first editions of James Joyce's Ulysses. From a technical point of view, Ulysses is well suited for this purpose because of its well-researched publication history and the large number of first edition copies sold in the observation period. ${ }^{5}$ From a literary-historical point of view, focusing on Ulysses does, of course, requires no justification. Since its publication, Ulysses has achieved overwhelming and sustained critical acclaim and enjoys nowadays the status of a landmark novel of $20^{\text {th }}$ century literature. In section 4, the hedonic regression method is applied the all 25 titles of the Fadiman 1960 selection to provide the nominal rates of financial returns to the titles in the observation period 1975-2018. Based on this sample of titles, I derive in section 5 rare book price indices using different specifications of hedonic regressions. Since my sample is not representative of all rare books, not even of rare books of $18^{\text {th }}-20^{\text {th }}$ century English fiction, the objective is limited to identifying the most efficient way of computing rare book price indices that can then be applied to larger samples of books. Apart from submitting the index to various robustness checks, I also provide indices for $18^{\text {th }}, 19^{\text {th }}$, and $20^{\text {th }}$ century books and quantile hedonic regressions that show how rates of return vary across price ranges of rare books. Section 6 then computes real returns of rare book collecting by deflating the nominal price index by the U.S. consumer price index and compares these real returns with real returns on fine art, gold, real estate, and two financial assets. Section 7 concludes.

\section{DATA}

Fadiman's The 1960 Lifetime Reading Plan lists, and briefly describes, 100 titles and suggests these books for a "lifetime reading" to Americans who have not met more than ten percent of the listed writers (Fadiman 1960, p. 20). The Reading Plan comprises nine categories: The Beginning (ancient Greek and Roman writers); The Middle Ages; Plays; Narratives; Philosophy,

\footnotetext{
${ }^{5}$ For the publication history of Ulysses, see Slote (2004).
} 
Psychology, Politics, Essays; Poetry; History, Biography, Autobiography; Some Contemporaries; and Miscellaneous. Focusing on fiction, only the categories Narratives and Some Contemporaries are relevant for this study. Among the 33 books listed in the Narrative section, 20 were written in English, among the remaining 13 books, six were written in French (Rabelais, Voltaire, Stendhal, Balzac, Flaubert, and Proust), four in Russian (Gogol, Turgenev, Dostoevsky, and Tolstoy), and one each in German (Thomas Mann), Spanish (Cervantes), and Norwegian (Undset). Among the eight listed Contemporaries, one is a poet (Robert Frost) and one a French writer (Malraux) which leaves us with 25 titles of fiction written in English. For most of these writers, Fadiman recommends one title. If more than one title is listed, I restricted myself to the first mentioned title to keep the sample balanced. ${ }^{6}$

The chosen selection criteria yield the following sample of titles, ordered according to the year of their first publication: The Pilgrim's Progress (1678) by John Bunyan, Robinson Crusoe (1719) by Daniel Defoe, Gulliver's Travels (1726) by Jonathan Swift, ${ }^{7}$ Tom Jones (1749) by Henry Fielding, Tristram Shandy (1759) by Laurence Sterne, Pride and Prejudice (1813) by Jane Austen, ${ }^{8}$ The Pickwick Papers (1836/37) by Charles Dickens, ${ }^{9}$ the short stories by Edgar Allen Poe (1840, 1845), Wuthering Heights (1847) by Emily Bronte, Vanity Fair (1848) by William Makepeace Thackeray, The Scarlet Letter (1850) by Nathaniel Hawthorne, ${ }^{10}$ Moby Dick (1851) by Herman Melville, The Mill on the Floss (1860) by George Eliot, Alice in Wonderland (1866) by Lewis Carroll, ${ }^{11}$ Huckleberry Finn $(1884 / 85)$ by Mark Twain, The Mayor of Casterbridge (1886) by Thomas Hardy, The Ambassadors (1903) by Henry James, Nostromo (1904) by Joseph Conrad, Sons and Lovers (1913) by D.H. Lawrence, Of Human Bondage (1915) by W. Somerset Maugham, Ulysses (1922) by James Joyce, Passage to India (1924) by E.M. Forster, In Our Time (1924) by Ernest Hemingway, Sound and Fury (1929) by William Faulkner, ${ }^{12}$ and Brave New World (1931) by Aldous Huxley. ${ }^{13}$

\footnotetext{
${ }^{6}$ Using, for example, all seven recommended Dickens titles would create an untoward bias towards this author whose books are already sold at auctions more often than the books by almost all other authors recommended by Fadiman.

${ }^{7}$ Fadiman also recommends three other titles by Swift: A Modest Proposal, Meditations Upon a Broomstick, and Resolutions When I Come to Be Old.

${ }^{8}$ Fadiman also recommends Austen's novel Emma.

${ }^{9}$ Fadiman also recommends six other titles by Dickens: David Copperfield, Bleak House, Great Expectations, Hard Times, Our Mutual Friend, and Little Dorrit.

${ }^{10}$ Fadiman also recommends Hawthorne's Selected Tales.

${ }^{11}$ Fadiman also recommends Through the Looking Glass, the sequel to Alice in Wonderland.

${ }^{12}$ Fadiman also recommends Faulkner's novel As I Lay Dying.

${ }^{13}$ Fadiman also recommends Huxley's Collected Essays.
} 
I use the American Book Prices Current (APBC) database that records on its online portal auction prices of books, manuscripts, autographs, maps, and broadsides sold at auction beginning in 1975. APBC basically covers auction houses in the United States and Great Britain. ${ }^{14}$ All prices listed are hammer prices, i.e. the percentage surcharge of the respective auction house that the buyer must pay on the winning bid, is not included. If the hammer price is not in US dollars, the platform also provides the price in USD converted at the time of the sale. As usual, buy-ins (items that are not sold) are not recorded.

Apart from the hammer price, the information provided by APBC includes typically a description of the identity of the book (author, title, date and location of publication, format, edition, issue, binding), details the condition of the book, refers to a bibliography of the author's works, and states the auction house that handled the transaction, the exact date of the sale, and the lot number. In total, this study makes use of 3402 auction sales retrieve from the APBC database.

\section{AN ENTRY-LEVEL EXAMPLE: JAMES JOYCE'S ULYSSES}

Ulysses makes the first appearance in print in The Little Review, an American literary magazine that serialized the novel from 1918 to 1921 when the Post Office refused to dispatch the magazine, arguing that Ulysses contained obscene passages. The ensuing obscenity trial prevented publication in the United States until 1934 and also foiled the plans for a publication in England because Harriet Shaw Weaver, Joyce's mentor and owner of the English Egoist Press, was not able to find a sufficiently daring printer. Joyce, who at that time lived in Paris, was lucky to find in Sylvia Beach, the American-born owner of the Paris bookstore Shakespeare and Company, an enterprising friend who made a point of publishing the timeless masterpiece to be. To reduce the commercial risk, the book was offered to subscribers. The first printing of February 1922 was limited to 1000 copies and consisted of 100 copies on Dutch handmade paper signed by Joyce, 150 copies on Arches paper, and 750 copies on handmade paper. The subscription prices amounted to 350 francs, 250 francs, and 150 francs, respectively (Exhibit 1). In 1922, the average annual income in the United States amounted to about 1400 USD and the exchange rate stood at about 10 francs/USD, implying that cheapest of the three versions

\footnotetext{
${ }^{14}$ In my sample, only a handful of books were sold by other auction houses. I assigned these observations to the US auction houses.
} 
still cost about 15 USD or about $13 \%$ of an average monthly US income (but then, the average American wage earner probably did not make habitual vacation trips to Paris in the 1920s).

The first English edition was published in October 1922 by Harriet Shaw Weaver's London-based Egoist Press. For legal reasons, this edition was officially published by John Rodker, at that time the foreign editor of The Little Review, on behalf of Egoist Press and printed by the same French printer and the same plates that were used for the Shakespeare and Company edition (Exhibit 2). Of the 2000 numbered copies, 500 were burned by the New York post office authorities. The same fate suffered the entire 1923 third printing that was seized by the custom's authorities in Folkestone (Exhibit 3). The sample used in this study is restricted to copies of the 1922 first and second printings.

My dataset covering the 1975-2018 period comprises 363 auction records of first- and second-printing copies of the first edition: 31 sales of the signed 100-series, 30 of the 150series, 153 of the 750-series of the Shakespeare and Company first printing, and 149 of the second printing for the Egoist Press. ${ }^{15}$ About 400 copies of the first Shakespeare and Company printing of 1000 copies are estimated to have survived in private ownership; the 214 recorded auction sales therefore indicate a turnover of about one half of this stock in 44 years. The number of sales varies across time, but in each year at least one was sold which allows constructing a price index without gaps.

Figure 1 provides a first impression of the price development of these Ulysses first editions. The prices are in US dollars converted to natural logarithms (In). The scatter diagram offers three insights. First, the signed copies of the Shakespeare and Company 100-series are the most sought-after, followed by copies of the 150-and the 750-series; copies of the second printing by the Egoist Press fetch lower prices that copies of the first printing. Second, even within these four groups and within short periods, prices vary a great deal. The printing history and the date of sale of a rare book are, therefore, far from explaining rare book auction prices. In the year 2000, for example, a copy of the 750-series sold for $\$ 800$ (In: 6.68), another one for $\$ 26.000$ (In: 10.16). Third, the log-prices increased across time in a rather linear manner, indicating an exponential increase in nominal prices.

\footnotetext{
${ }^{15}$ Even though the sample is restricted to first- and second-printing copies, several other editions are also highly collectable and sold at auctions.
} 


\section{FIGURE 1: LOG PRICES OF ULYSSES}

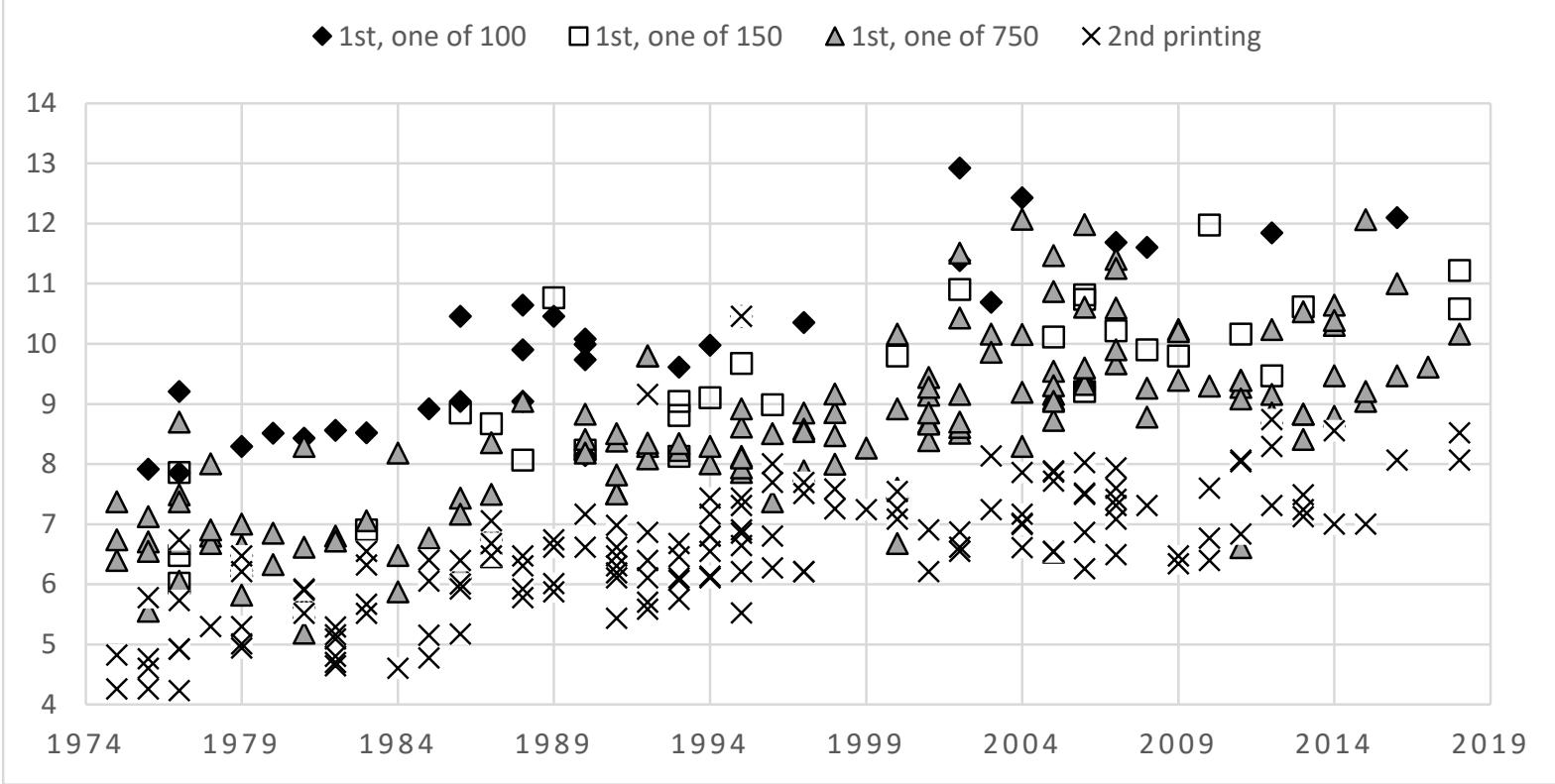

The reasons for the large observed variance of rare book prices that remains unexplained after taking the transaction date and the book's identity (in this case the three versions of the first printing, and the second printing) into account are manifold. The book's condition is often claimed to explain a large part of the unexplained variance. The two auction prices of $\$ 800$ and $\$ 26.000$ fetched in the year 2000 for otherwise identical books can, for example, be explained by the description of their condition by Christie's East (New York) where both books were sold (Exhibit 4). The expensive copy was still bound in the original wrappers and had only rather minor blemishes for an almost 100-year-old paperbacked book, the more modest copy was rebound in half morocco (which is a nice binding - but not the sought-after, original, one) and the title page, the half title and a portion of a page was supplied in facsimile. It was sold "w.a.f", i.e. with all faults that the auction house does not even bother to detail. Such a description is never a good sign. Other factors that may contribute to explaining price differences include fine bindings, variations indicating an especially early state within an issue, included or lacking pictures and maps, inscriptions by the author, and a provenance that relates the book to a notable previous owner or prominent collector. A good predictive model that acknowledges the heterogeneity of otherwise identical rare books is the hedonic regression model that identifies and estimates the weights of the various determinants of rare book price formation. Our first hedonic regression model 
presumes that rare book prices develop exponentially over time (the second model will then replace the time trend with year-of-sale dummy variables):

$$
\ln p_{i t}=\alpha+\sum_{j=1}^{n} \beta_{j} x_{j i t}+\delta t+\varepsilon_{i t}
$$

The dependent variable, $\ln p_{i t}$, is the natural logarithm of the US dollar hammer price of book $i$ sold in year $t, x_{j i t}$ denotes characteristic $j(j=1, \ldots, n)$ of book $i$ sold in year $t, \delta$ the time trend of the log-price, and $\varepsilon_{i t}$ represents the error term. Table 1 reports the estimates of $\alpha, \beta_{j}$, and $\delta$ for different specifications. The first regression does not include any of the characteristics $x_{j i t}$, the second one uses only the four considered versions of first edition Ulysses as price relevant characteristics: $x=($ one of 100, one of 150, one of 750), where the three components (the title-specifics) of vector $x$ are dummy variable assuming the value one if book $i$ is of the indicated series, and zero otherwise; the second printing books (one of 2000) serve as the reference category. The estimates reported in columns 1 and 2 of Table 1 support the impression provided by the scatter diagram in Figure 1: prices increase steadily across time and the three types of first issue copies published by Shakespeare and Company are priced much higher (and the relative prices are ordered as expected) than second issue copies published by the Egoist Press. The value added of the statistical analysis is that the regressions yield an estimate of the price increase across time. Using the estimate $\hat{\delta}$, which amounts in both regressions to 0.085 , one arrives at an estimated average annual rate of price increase of $e^{0.085}-1=8.8 \%$.

\section{Table 1 at the end of the paper}

Even though regressions (1) and (2) in Table 1 both arrive at the same estimate for $\hat{\delta}$, the adjusted $R^{2}$ is much higher in regression (2) that distinguishes between the four types of Ulysses. In the following three regressions, I test whether this estimate is robust to including in vector $x$ further variables that may explain some of the remaining variance. Regression (3) includes five seller-specific variables, i.e. variables that indicate where the sale took place. The UK variable assumes the value 1 if the transaction was conducted by an auction house in the United Kingdom, the reference group comprising sales by auction houses in the United States. ${ }^{16}$ By differentiating between sales in the UK and the US, one may be able to identify a

\footnotetext{
${ }^{16}$ Only very few auction sales recorded in our sample were conducted by auction houses based in other countries. These transactions are relegated to the reference group (US).
} 
possible bias of collectors to buy mainly in the UK or the US. The auction house variables indicate whether the transaction was conducted by Christie's or Sotheby's. Since both of these auction houses have salesrooms in London and New York, this results in four variables. The reason for including these four auction-house variables is that books sold by Christie's or Sotheby's may fetch a higher price, either because these highly reputed institutions attract an especially high spending power audience, or because they only accept high-quality lots which would then serve as a quality signal of the auctioned books.

Regression (3) also includes two variables referring to provenance. The variable special indicates whether a book was owned by a famous person or was part of a well-known collection. Books signed or even inscribed by the author usually fetch higher prices than unsigned books and so do association copies, i.e. books once owned by someone connected with the author or, in rare cases, the story-line of the book. The highest priced copy of Ulysses in the sample is, not surprisingly, inscribed by James Joyce. It was sold in 2002 by Christie's in New York for $\$ 410.000$ hammer price (hammer price plus buyer's premium amounted to $\$ 460.500)$. This copy is a first printing of the one-of-100 issue (however out-of-series and unsigned on the limitation page) and inscribed by Joyce to the Lausanne publisher Henry Kaeser on the flyleaf: "To Henry Kaeser James Joyce Dijon 12 October 1922" (Exhibit 5). Presentation copies of this issue are very scarce: only nine copies of the 59 copies that were located have presentation inscriptions from Joyce. Of these nine, seven are in institutional libraries. ${ }^{17} \mathrm{~A}$ nice example for an association copy is the first printing of the one-of-750 issue sold by Bonhams in 2014 for $£ 25.00$ (\$1.890), a rather stiff price at the time for a copy of this issue. This copy belonged to one Peter Mrosovsky, a fellow student at Cambridge of Vladimir Nabokov's. In his autobiography Speak, Memory, Nabokov describes Peter Mrosovsky storming into his digs with a copy of Ulysses freshly smuggled from Paris, stomping up and down and regaling him with one or two spicy passages from Molly' monologue. ${ }^{18}$ (Exhibit 6)

Including the auction-house and provenance variables has no significant effect on the estimated rate $\delta$ of the yearly increase in the price for first edition Ulysses. The estimates reported in column (3) of Table 1 also show that the estimated price differences across the four considered versions are not affected. Among the auction house variables, only the

\footnotetext{
${ }^{17}$ https://www.christies.com/lotfinder/Lot/joyce-james-ulysses-paris-shakespeare-and-company-3984062details.aspx

${ }^{18}$ Neil Cornwell: James Joyce and the Russians, MacMillan, London, 1992 (p. 71)
} 
coefficient estimates of the Sotheby's London, Sotheby's New York and Christie's New York turn out to be statistically significant; the UK coefficient estimate does not reach statistical significance at the $10 \%$ level by a hair's breadth. The estimates thus indicate that sales of Ulysses by Christie's and Sotheby's fetch higher prices than sales by other auction houses, whereby this effect may be restricted to the New York salesrooms of these two auction houses because of the possibly negative effect of sales in the UK. Among the provenance variables, the estimated price effect of signatures is positive and economically and statistically significant, whereas the positive special provenance effect is, if anything (with a p-value of 0.104), rather small. Notice, finally, that adding the seven additional variables increases the adjusted $\mathrm{R}^{2}$ only by $5 \%$ as compared to the rather parsimonious specification (2).

The arguably most important determinant of the value of a rare book copy is its condition. Condition is therefore a variable that needs to be considered when running hedonic book price regressions. In the present case, including condition can also serve to check whether Christie's and Sotheby's attract audiences with more purchasing power or manage to acquire higher quality lots. If Christie's and Sotheby's simply manage to cream skim the supply, the auction house variables are not more than condition indicators. Coding the condition of books sold at auctions is however a tricky business. First of all, the condition is not always reported and, second, if the condition is reported, the description varies across auction houses and time which makes coding somewhat subjective if not arbitrary. To minimize coding errors deriving from these problems, a rather coarse classification is called for. The employed condition index distinguishes four categories: (1) borderline collectable, (2) subprime, (3) collectable, and (4) eminently collectable. Adding this condition index to the set of explaining variables produces the estimates reported in column 4 of Table 1 . The estimates of the year of sale coefficient and the issue coefficients turn out to be robust to the inclusion of the condition index. The auction-house effects (with the exception of Sotheby's London) and also of the effect of special provenance do however disappear. All of these variables appear to pick up some aspects of the books' condition. The coefficient of the condition variable is fairly large and statistically significant at the $1 \%$ level. The adjusted $\mathrm{R}^{2}$ increases by another $5 \%$ as compared to specification (3). Since the condition index assuming the values from 1 to 4 presupposed linearity, it is interesting to check whether this restriction is defensible. Replacing the condition variable with four condition dummies (category 3 which comprises more than $50 \%$ of the observations serves as the reference category) one arrives at the estimates 
reported in column 5 of Table 1. The estimated coefficients of the condition dummy variables are perfectly in line with what was to be expected. They are perhaps somewhat more compressed in the middle categories than at the extremes but since the coefficient estimates of all the other variables remain fairly unchanged and the adjusted $R^{2}$ increases only marginally, the condition index appears to be an acceptable measure.

The last robustness test of the estimated rate of change in the price of first edition Ulysses allows for different rates of price changes for the two considered printings. Distinguishing copies of the three Shakespeare and Company versions from copies of the Egoist Press implies including an interaction of the year of sale with a dummy variable $y_{i}$ that assumes the value one if copy $i$ is a first printing (Shakespeare and Company) and zero otherwise (i.e. when copy $i$ is a second printing published by Egoist Press):

$$
\ln p_{i t}=\alpha+\sum_{j=1}^{n} \beta_{j} x_{j i t}+\delta t+\theta y_{i} * t+\varepsilon_{i t}
$$

The estimates of this specification are reported in column 6 of Table 1. Again, the estimates of all covariate coefficients remain fairly unchanged; the coefficient of the crucial Year of sale variable drops to 0.073 which implies that the price of second printings of Ulysses has increased over the last 44 year at a rate of $e^{0.073}-1=7.6 \%$ whereas the price of first printing copies increased at a rate of $e^{0.073+0.016}-1=9.3 \%$. The coefficient of the interaction variable Year*1 $1^{\text {st }}$ printing is statistically significant but small enough to let me bundle the two issues with a quiet conscience.

The rates of return of first and second printings of Ulysses as estimated by the regressions results reported in Table 1 are, of course, average rates which need not trace the price development in any sub period adequately. Only a price index can provide this kind of information. To construct a price index, the hedonic regression model (1) needs to be modified by replacing the year of sale variable $t$ by year of sale dummy variables for each year. The hedonic regression model then has the following appearance:

$$
\ln p_{i t}=\alpha+\sum_{j=1}^{n} \beta_{j} x_{j i t}+\sum_{t=1}^{43} \gamma_{t} Y_{t}+\varepsilon_{i t}
$$

where the dummy variable $Y_{t}$ assumes the value 1 if copy $i$ was sold in year $t>0$. For the initial reference year $\mathrm{t}=0$ the year of sale dummy $Y_{0}$ is set equal to 0 . The second sum in model 
(2) runs from $1975(t=0)$ to $2018(t=43)$. The estimated values $\hat{\gamma}_{t}$ can then be used to construct the hedonic price index $I_{t}$ by setting $I_{t}=100 * e^{\widehat{\gamma}_{t}}$. The resulting price index $I$ thus measures pure time effects because it is based on constant-quality prices, i.e. price effects that are not attributable to the included $\mathrm{n}$ hedonic characteristics $x$.

Using the preferred specification that corresponds, apart from replacing $t$ with the year dummies $Y_{t}$, to the fourth specification in Table 1, one arrives at the estimates reported in column (7) of Table 1 (the estimates of year dummy coefficients are not shown). The coefficient estimates of the covariates remain basically unchanged as compared to the baseline specification (4); the adjusted $\mathrm{R}^{2}$ increases from $88 \%$ to $90 \%$. The price index derived from the estimated year dummy coefficients are depicted in Figure 2. The progression of the price index indicates that the prices were extremely volatile, which comes perhaps as no surprise because in some years only very few sales are reported in our dataset, notably in the year 2017 in which only one transaction is reported.

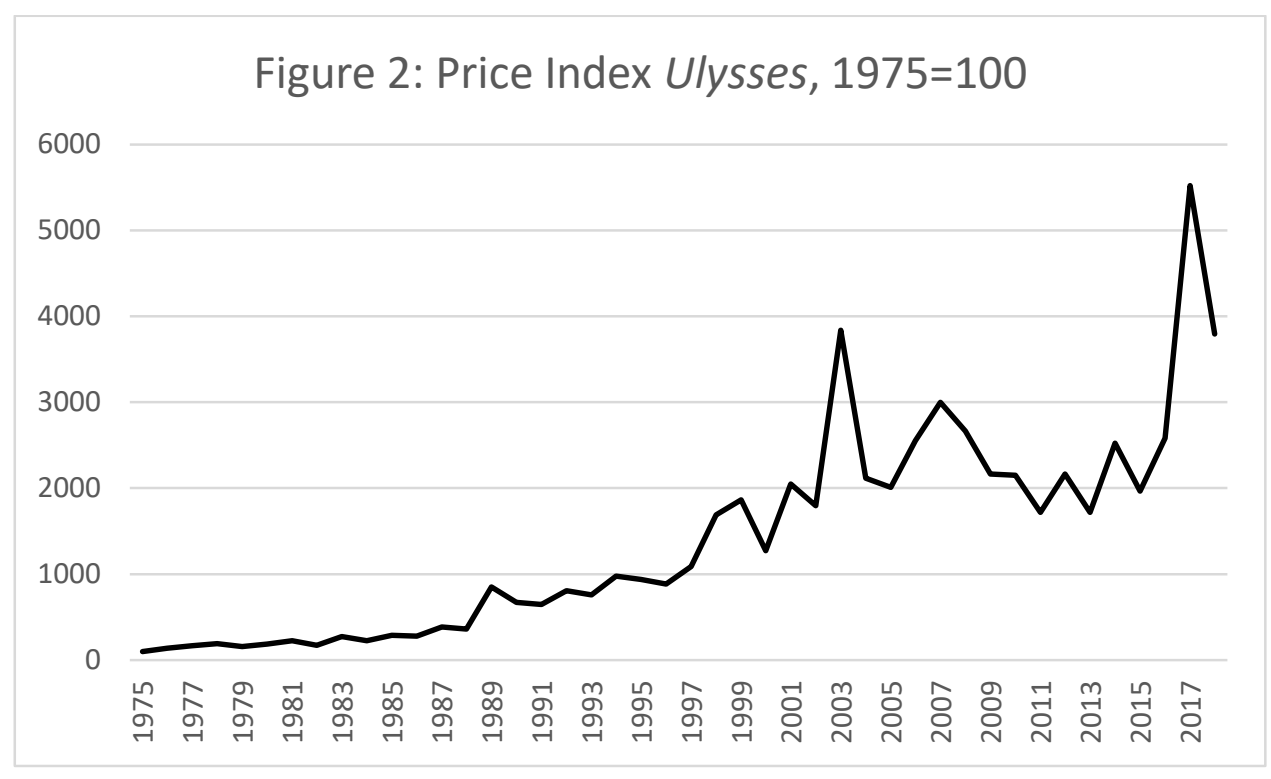

Apart from the year to year volatility, the index also indicates substantial long run deviations from the exponential trend. Figure 3 depicts the logarithmized index together with the associated linear trend estimated in the baseline specification. The figure clearly conveys that in the entire 20-year period 1988-2008, Ulysses prices were higher than indicated by the estimated trend and underperformed before and afterwards, only to catch up at the current edge. 
The question whether the short-run volatility is reduced when considering an entire portfolio of rare books and whether the long-run pattern of price development identified for first-edition copies of Ulysses is typical for a broader selection of rare book titles will be answered in Section 5. In the following section, the long run-return of all 25 titles included in the Fadiman 1960 selection are estimated with the hedonic method presented in this section.

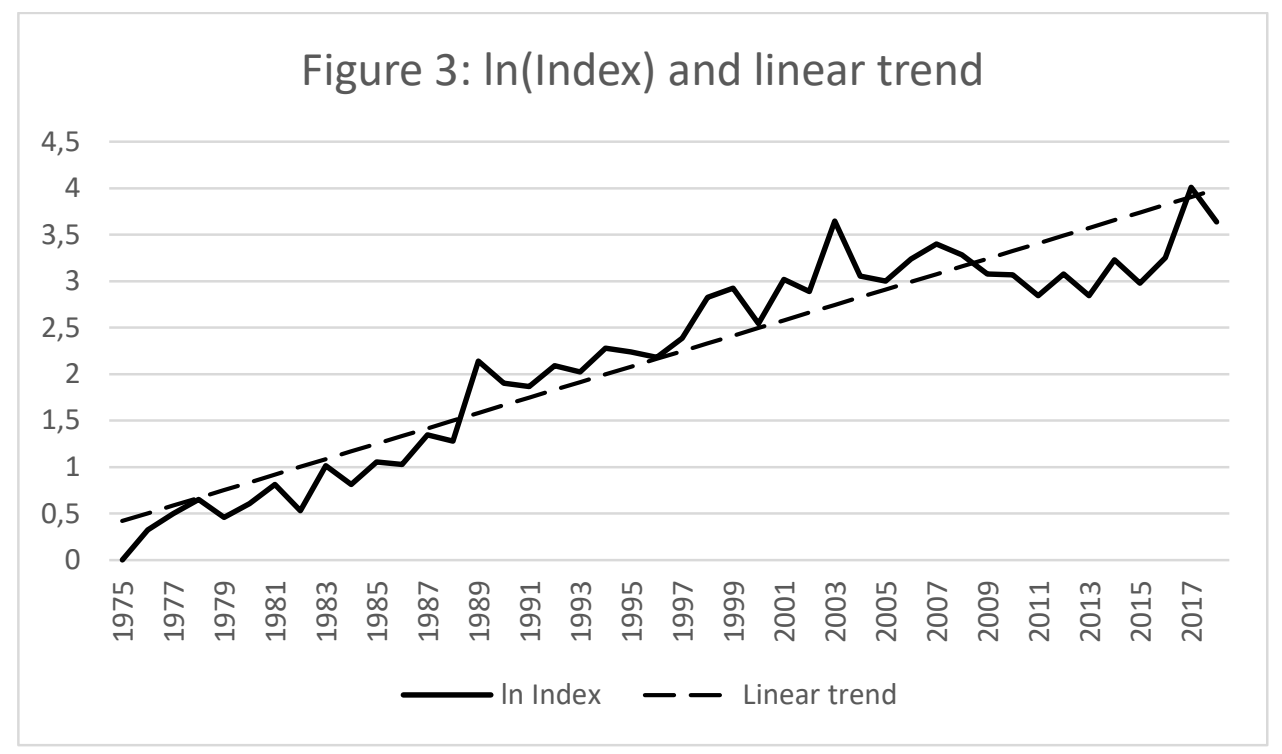

\section{THE RATES OF RETURN OF THE 1960 FADIMAN SELECTION NOVELS}

The estimates resulting from the hedonic regression model (1) presented in the previous section indicate that the market price for first-edition Ulysses increased by close to 9 percent per annum in the period 1975-2018. To examine whether this substantial rate of (nominal) return is at all representative of rare books that are in the same league of artistic value, I estimated this model for all 25 (English) fiction titles recommended by Fadiman (1960) by using specification (4) in Table 1, i.e. the baseline specification that includes the full set of covariates. The coefficient estimates $\hat{\delta}$ of the 25 titles' time trends are reported in Table 2 together with the associated average annual rates of return $r=e^{\widehat{\delta}}-1$. Since the "titlespecific" covariates differ by definition across titles, brief comments on some of the publication histories are called for. For the impatient reader, the gist of the results reported in Table 2 can however be summarized as follows: the nominal prices of all titles in the Fadiman sample increased over the observation period, albeit at different rates, and all of these estimated price trends are all statistically significant at the $1 \%$ level. 
The first five entries in Table 2 report the estimated rates of nominal returns of the five titles that appeared in the $18^{\text {th }}$ century. Bunyan's Pilgrims Progress actually appeared already in the $17^{\text {th }}$ century, in 1678 to be precise, but only one auction sale of a $1^{\text {st }}$ edition is reported in ABPC and only $16(18)$ Pilgrims printed in the $17^{\text {th }}\left(18^{\text {th }}\right)$ century were sold in the observation period. I therefore included all those sales, added for good measure the 45 sales of $19^{\text {th }}$ century editions (up to 1898) and, to top it off, 31 sales of the 1899 Essex House Press edition limited to 750 copies and 44 sales of the nicely illustrated 1928 Cresset Press edition which was limited to 195 copies and to ten copies with an extra suite of plates. Because of the scarcity of early editions of Pilgrim's Progress, a collector in the 20the century would probably also have considered buying one of these Essex House and Cresset Press editions that actually turned out to be eminently collectable. ${ }^{19}$ To accommodate this large variety of edition, I thus estimated model (1) by including title-specific dummy variables for editions published in the $17^{\text {th }}, 18^{\text {th }}$, and $19^{\text {th }}$ century up to 1898 , the 1899 Essex House Press edition, and the two versions of the 1928 Cresset Press edition. As in model (1'), I also interacted time with $17^{\text {th }}$ century editions. The average annual rate of return on $17^{\text {th }}$ century editions of Pilgrims Progress turns out to be $10.3 \%$.

Defoe's Robinson came originally in three volumes: The Life and Strange Surprising Adventures of Robinson Crusoe, The Farther Adventures of Robinson Crusoe, Being the Second and last part of his life, and Serious Reflections During the Life and Surprising Adventures of Robinson Crusoe with his vision of the Angelick World. The first two volumes were printed in 1719 and reprinted often in the same year and later on. The third volume was not as popular as the first two volumes and was never reprinted, making auction sales of sets of all three volumes a rare event. I therefore distinguish between lots of all three volumes and lots containing only the first two. Since the sets are often composed of volumes of different editions, I control for sets containing volumes of later editions.

Following H. Teerink, the bibliographer of Swift's writings, three editions of Gullivers published in 1726 are distinguished: Teerink's " $A$ ", the first edition, followed by the " $A A$ " and " $B$ " editions. All of these editions came with 6 plates (maps) and a frontispiece. Apart from distinguishing " $A$ " and "AA" copies from " $B$ " copies (statistically significant), I also employ dummy variables that explicitly indicate the presence of the frontispiece and all plates (not

\footnotetext{
19 On the AbeBooks website (as of November 2019), for example, two copies of the one-of-195 version of the Cresset Press 1928 edition are offered for sale for more than 1000 Euros.
} 
significant), a very scarce first-state frontispiece (significant), and copies on large paper (significant).

The six-volumes first edition of Fielding's masterpiece, Tom Jones, consisted of 2000 copies. Almost all of them were already sold before publication. The copies of the first edition are identifiable because they include a page of errata in the first volume. The errata were corrected in the second edition of 1500 copies. Both editions were offered for sale on the first day of publication. I nevertheless included a dummy variable indicating first editions copies and find that today's collectors are prepared to pay significantly higher prices for first than for seconds editions.

Sterne's Tristram Shandy was published over seven years, beginning in 1759 (but postdated 1760), in nine volumes. The first two volumes were published by Sterne himself, a second edition of these volumes was published in 1760 by Sterne's London bookseller who, in 1761, also published volumes 3 and 4. Volumes 5-9 were again published by Sterne between 1762 and 1767 . Given this publication history it is not surprising that many sets sold at auctions contain volumes that are not first editions. I therefore distinguish between sets of first editions and mixed sets. ${ }^{20}$ Sets of first editions fetch significantly higher prices than mixed sets. Stern was very concerned about piracy of his work and therefore signed the first editions of volumes 5, 7 and 9 (and also the second editions of volume 5). Signed editions are, as a consequence, almost the rule. This is why including the variable signed does not influence the estimate of the main explanatory variable.

Moving now to books published in the $19^{\text {th }}$ century (see the next 11 titles in Table 2), the first one, published in 1813, is Jane Austen's Pride and Prejudice. No title specifics needed to be included in this regression because all first editions are identical. Among all 25 books in the Fadiman 1960 selection, Pride and Prejudice reaches the highest estimated rate of return. With $11.5 \%$ its average annual rate of return is more than twice as high as the returns of some of the other titles in the sample.

Many $19^{\text {th }}$ century novels were first published in serialized, wrapper-bound parts that were sometimes even reprinted before serialization was complete. These parts were then either bound into a book according to the specifications of the owner or simply preserved in parts (Exhibit). Only after serialization was complete, the novel appeared in book form. First editions in original parts are, as a rule, more sought-after than first editions in book form which

\footnotetext{
${ }^{20} \mathrm{~A}$ variable reporting the number of fist edition volumes in the set of nine did not provide any value added.
} 
often come in various issues that can only be told apart by so-called points, i.e. features or characteristics that identify a copy as being of a particular issue or state. Dickens's and Thackeray's novels were both published that way. The regressions relating to the Pickwick Papers and Vanity Fair therefore include (title-specific) dummy variables distinguishing between first editions in original parts and in book form and, second, between early and late book issues. In the case of the Pickwick Papers, an additional novel-specific variable indicating copies with extra illustrations is included. All these novel-specific characteristics and most of the other hedonic characteristics are statistically significant.

Edgar Allen Poe's stories made their first appearance in book form in 1840. This collection of 25 stories in two volumes was entitled Tales of the Grotesque and Arabesque. A second collection of 12 stories, the Tales, appeared in 1845. I use both titles, first because Fadiman did not recommend one specific collection but Poe's tales in general, and, second, because the two collections are somewhat interchangeable; two of the stories actually appear in both collections. Also in 1845, a reissue, using sheets from the second and third printing of the Tales, was published together with the The Raven and other poems. I use this so-called Reissue $B$ together with the Tales of the Grotesque and Arabesque and the first printing of the Tales as title-specific dummy variables, the reference group comprising the other printings of the Tales.

Collectible first editions of Emily Bronte's Wuthering Heights were published more or less at the same time by English and American publishing houses. The same applies to Melville's Moby Dick, Lewis Caroll's Alice in Wonderland, and Mark Twain's Huckleberry Finn. ${ }^{21}$ It is perhaps not surprising that English first editions of Wuthering Heights are more expensive than the American first editions; after all, Emily Bronte was an Englishwoman. Applying this rule to Moby Dick and Alice in Wonderland does, however, not work out. The reasons may be that Moby Dick was first published under the title The Whale in a rather small edition of 500 copies in London and only a month later in New York in an edition of almost 3000 copies. Priority and relative scarcity may thus explain the statistically significant price difference.

In the case of Alice in Wonderland it may also be the publication history that explains why first editions published by Appleton in New York fetch higher prices than first editions published by Macmillan in London. The "real" first printing of 2000 copies for Macmillan was

\footnotetext{
${ }^{21}$ The $20^{\text {th }}$ century novel Of Human Bondage by W. Somerset Maugham was also published at the same time in London and New York.
} 
held back by Carroll because the book's illustrator, John Tenniel, told him that the print quality of the pictures was unacceptable. Carroll gave in and payed for a second printing. The text blocks were removed from the binding and sold to Appleton to be rebound with a new title page. The English first editions that are commonly sold at auctions are thus second printings, whereas the American first editions feature the text block of the first printing which may explain the higher desirability of the American first editions. Fifty advance copies of the first English printing were actually delivered to Carroll who used them as presentation copies. But of these 50 copies only 23 survived, of which all but five are now in public libraries. In the ABPC sample, only three auction sales of these "real" first editions are reported (one sold in 1980 for $\$ 53,000$, one in 1986 for $\$ 64,000$, and one, Carroll's own copy with pencil drawings of the illustrations by Tenniel, in 1998 for $\$ 1,400,000)$; they are however not used in the hedonic regression. In 2016 Christie's New York offered, at an estimated price of 2-3 million USD, another copy in outstanding condition and with remarkable provenance for sale, but this lot failed to meet its reserve and did not sell.

Huckleberry Finn was first published in England and Canada in December 1884. Publication in the United States was delayed until February 1885 because a printer's employee defaced the plate for one of the illustrations, with the consequence that a new plate had to be created. ${ }^{22}$ The American first editions were sold by subscription and came in a variety of bindings: 2500 copies in sheepskin at the price of $\$ 5$, some 500 in half morocco leather at $\$ 4$, and 10,000 in in pictorial cloth at $\$ 3$. Of the copies bound in pictorial cloth, 500 are in blue, the remaining copies in green, probably because the author did not like the first run and demanded that the colour was change to green (the reference category in the regression). Apart from the different types of bindings, one can distinguish different issues: first, early, mixed, and later issues (the reference category). The estimates indicate that those titlespecific characteristics are economically and statistically significant price determinants. Copies bound in original half morocco are more expensive than copies bound in blue pictorial cloth which, in turn, are more expensive that copies bound in sheepskin. Least expensive are copies in green pictorial cloth. Again, scarcity appears to determine prices. Also not surprising is that first issues are more expensive than early or mixed issues which are more expensive than later issues. Moreover, it turns out that the estimated ceteris paribus price of English first editions does not differ from the estimated price of later issue American first editions.

\footnotetext{
${ }^{22}$ https://philipzamora.files.wordpress.com/2013/01/1819113-publication-of-huckleberry.pdf
} 
Just as Pride and Prejudice, three more titles in the $19^{\text {th }}$ century subsample do not feature any title-specific distinguishing marks, Hawthorne's Scarlet Letter, Eliot's Mill on the Floss, and Hardy' Mayor of Casterbridge.

The last nine entries in Table 2 report the estimated rates of nominal price changes of the nine titles of the Fadiman sample that appeared in the $20^{\text {th }}$ century. The estimate for Ulysses are replicated from column 4 of Table 1.

The Ambassadors by Henry James was serialized by the literary magazine North American Review before publication in book form in September 1903 by the publishing house Methuen in London and two weeks later by Harpers in New York. Because Harpers worked from the serial-version proofs which contained abridgments and Methuen from the original unrevised typescript, the two editions exhibit marked differences including the placement of an entire chapter that was not included in the serial version. Despite the facts that the American born James spent most of his adult life in Europe and the British first edition with its many interesting differences predates the American first edition, the American first edition appears to be preferred by the collectors: only one out of 34 first-edition copies recorded by $A B P C$ is a Methuen copy. This is why the regression for The Ambassadors does not include a novel-specific variable that differentiates between the English and the American first edition. ${ }^{23}$ Moreover, since all copies sold in the UK were sold either by Christie's or Sotheby's, the regression does not include the $U K$ dummy variable. The regression results show that the average rate of return of a first-edition Ambassador, a critically acclaimed novel which also the author thought to be his best, was much lower at $6.0 \%$ than that for Joyce's Ulysses at 8.7\%. The next title, Conrad's Nostromo, is also a case in which no title specific variables need to be considered because the first edition is well defined and demarcated from close substitutes.

The first English edition of Sons and Lovers by D.H. Lawrence comes in three different states or variants: copies with a dated cancel (i.e. a tipped in) title page and copies with an integral title page that is either dated or not. No clear priority among these variants has been established. To test whether the market gives priority to the cancel-title version which is, according to the first bibliographer of Lawrence's work (Warren Roberts), often considered to be the first issue, I differentiate between this " $1^{\text {st }}$ version" and the other ones (reference

\footnotetext{
${ }^{23}$ When including a dummy variable for the only Methuen observation, the estimated coefficient of this variable does not turn out to be statistically significant and all the other estimates remain basically unchanged.
} 
category). The estimated price premium of this version turns out to be positive but statistically not significant $(p=17.4 \%)$.

William Somerset Maugham was in the first half of the $20^{\text {th }}$ century one of the most popular writers, and very likely the highest-payed one. He wrote novels, plays and short stories. When including Maugham's Of Human Bondage in his 1960 Lifetime Reading Plan, Fadiman realized that he was making a risky decision because Maugham was not an innovative novelist. Fadiman therefore explained at some length his decision by referring to Maugham's superb craftsmanship and the general readability of his books. In the second, revised edition of the Lifetime Reading Plan that appeared in 1978, Fadiman however recanted his decision, dropped Maugham and explained that "over two decades one's perspectives and indeed one's tastes change," while still holding that Of Human Bondage remains well worth reading even though it does "not today loom as large as (it) did a couple of decades ago" (Fadiman 1978, p. 1). ${ }^{24}$ This change in taste does, however, not appear to have had an unfavorable effect on the price of first editions of Maugham's novel. The estimated rate of return of $6.5 \%$ is well in line with the rate of return estimates of some of the other titles that are all regarded to be landmarks of literary history. Maugham was perhaps even more famous in the United States than in his native England; it is therefore not surprising that the American first editions published by Doran in New York are not cheaper than the English first editions published by Heinemann in London.

The first edition of Forster's Passage to India comes in two versions: a signed version on large paper in a limited edition of 200 (33 of the 99 sales reported in the ABPC sample) and the normal first trade edition. Apart from differentiating between the limited edition and the normal one (reference category), a distinction is made between copies with a dust jacket $(\mathrm{d} / \mathrm{j})$ and copies without. The same title-specific characteristics are used in the regression for Huxleys's Brave New World (last entry). The price premium for limited edition copies and copies with dust jackets is in both cases statistically significant at the $1 \%$ level; again no surprise for bibliophiles.

Hemingway's collection of short stories entitled in our time (with a lower case title) was first published in 1924 by the Paris based Three Mountains Press in a limited edition of 170 copies. The first American edition which included 14 more stories appeared in 1925, the

\footnotetext{
${ }^{24}$ Since Maugham died in 1965, Aizenman and Kletzer's (2011) "citation death tax" may have helped to make this decision.
} 
first English edition in 1926. The regressions are based on the most sought after first Paris edition. No title-specific characteristics are therefore distinguished. Probably because of the small sample size, most coefficient estimates of the covariates are not statistically significant. The estimated annual return however is, and at a whopping $9.7 \%$. In the $20^{\text {th }}$ century sample, this rate of return is only surpassed with $10.2 \%$ by Faulkner's Sound and Fury. Interesting in the Sound and Fury regression is the negative coefficient estimate of the UK dummy variable that is statistically significant at the $1 \%$ level. The question arises whether rare books authored by American (British) authors fetch, as a rule, higher prices at American (British) auctions.

Figure 4 sums up the results for the main explanatory variable. Judging from the Fadiman 1960 sample of English language novels, one arrives at the conclusion that the average annual price increase of rare books ranges from $4.6 \%$ to $11.9 \%$ or, bolder and simpler: Jane beats them all. ${ }^{25}$ Because many of the books were not sold very often during the observation period, some of the estimated returns have quite large standard errors. The differences in return estimates between any two titles are therefore only statistically significant for individual book pairs.

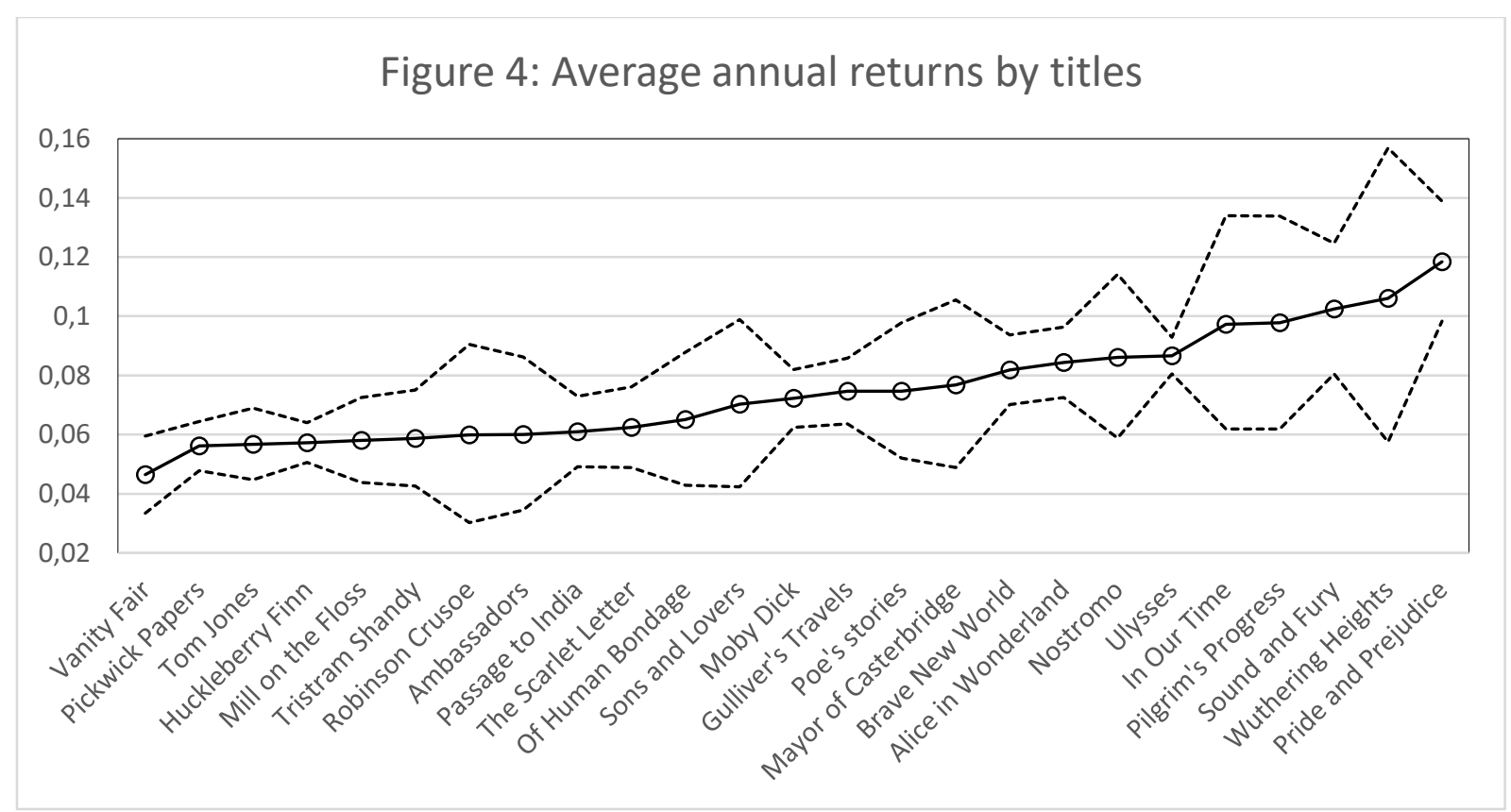

Note: $95 \%$ confidence intervals are indicated by the dotted lines.

\footnotetext{
${ }^{25}$ Explaining the differences in returns would, of course, be an intriguing endeavour, especially for a larger sample of rare books. Potential determinants that spring to mid are the number of first edition copies that survived in private collections and the popularity of the author with contemporary readers.
} 
As far as the other covariates are concerned, the detailed results (not shown) suggests that the title-specific features usually do have a statistically significant price effect, the auction house dummies have the expected positive sign if they are statistically significant, whereas the coefficient estimates of the dummy variable indicating a sale in the UK in most cases do not turn out to be statistically insignificant. The provenance and condition variables do, however, usually have the expected effect and are statistically significant. Since many of the statistically insignificant estimates may be due to the small sample size when estimating model (1) for the 25 included books separately, it is worthwhile to check whether one can estimate the effect of the covariates more precisely when bundling the observations of all 25 titles. The regression result that includes title fixed effects (not shown) for all but one of the 25 included books are reported in column (1) of Table 3 (at the end of the paper). The estimates show that with the exception of the UK dummy variable, all other reported independent variables are statistically significant at the $1 \%$ level and have the expected signs.

\section{THE PRICE INDEX OF THE FADIMAN SELECTION}

\subsection{Descriptive statistics}

The number of pertinent auction sales recorded in the observation period 1975-2018 by ABPC amounts to 3402 . The distribution of the number of observations across time is shown in the first panel of Figure 5. The comparatively small number of observations in the last three years derives perhaps from ABPC's rather long time lag in collecting the information. In any event, the available number of observations in each year is sufficiently large to allow estimating a meaningful price index. The bulk of the distribution of the nominal hammer prices is shown in the second panel. The distribution is truncated at $\$ 10,000$, some 425 lots fetched however much higher prices as shown in the third panel. The most expensive book in the entire sample is the copy of Ulysses inscribed by James Joyce to Henry Kaeser which was sold in 2002 by Christie's in New York for $\$ 410,000$.

\section{Figure 5 at the end of the paper}

The distribution of the covariates is shown in the following three panels. About one third of the sales in the sample were conducted by auction houses in the United Kingdom, two thirds in the United States. Most of the sales in the UK were handled by Sotheby's or Christie's (about 61\%), whereas in the US those two auction houses handled only about one third of the sales. Together, Sotheby's and Christie's were responsible for about $43 \%$ of all sales in the 
sample. Relatable provenance is not an uncommon feature of rare books. About $7.5 \%$ of the books in the Fadiman sample are signed and about $17.5 \%$ came from libraries of known collectors. The applied classification of the books according to condition produced the following distribution across the four categories: $47 \%$ of the books were in a condition that makes them highly collectible (condition index 3 ) and $15 \%$ were even classified as being in prime condition (condition index 4). Among the less desirable copies, $32 \%$ were still judged to be in an acceptable condition (condition index 2 ), whereas $6 \%$ were in rather poor shape (condition index 1).

\subsection{Estimating rare book price indices based on the Fadiman 1960 sample}

To estimate a rare book price index for the entire Fadiman 1960 sample of English fiction, model (2) needs to be modified by including title fixed effects. The dependent variable now represents to the natural logarithm of the US dollar hammer price of book $i$ with title $k$ sold in year $t$. The new variables represent the title fixed effects that assume the value $v_{i k}=1$ if observation $i$ has the title $k$ and zero otherwise (the reference title is Ulysses).

$$
\ln p_{i k t}=\alpha+\sum_{j=1}^{m} \beta_{j} x_{m i}+\sum_{t=1}^{43} \gamma_{t} Y_{t}+v_{i k}+\varepsilon_{i t}
$$

It is by now well known that the price index $I_{t}=100 * e^{\widehat{\gamma}_{t}}$ tracks the geometric mean of prices across time and not the arithmetic mean which investors use when making purely financial decisions. Even though it is not clear which index should be used when tracking the prices of collectibles as long as the intended purpose of the index is not well defined (Vecco and Zanola 2017), I present an easily available index that corrects for the bias in the standard index $I$ induced by the log transformation of the prices. I follow Renneboog and Spaenjers (2013) and construct the "corrected" art price index which is defined as follows:

$$
I_{t}^{c}=100 * e^{\left(\widehat{\gamma}_{t}+0.5\left(\widehat{\sigma}_{t}^{2}-\widehat{\sigma}_{0}^{2}\right)\right)}
$$

where $\hat{\gamma}_{t}$ denotes the coefficient of the time dummy $Y_{t}$ estimated in regression (3) and $\hat{\sigma}_{t}^{2}$ the estimated variance of the residuals in year $t$.

The OLS results of regression model (3) with standard errors adjusted for the 25 title clusters are reported in the second column of Table 3. Comparing the estimates with the 
estimates reported in the first column indicates that the estimates are pretty stable when replacing the year-of-sale variable (column 1) with year dummies (column 2). Also the adjusted $\mathrm{R}^{2}$ does not increase as much as one might have expected. The estimated coefficient of the UK variable remains statistically insignificant, implying that, apart from sales at Sotheby's and Christie's, auction prices fetched at British and American auctions do not differ. Books sold at Sotheby's and Christie's do however fetch higher prices, i.e. the respective four auction house effects are positive and statistically and economically significant, be it because those auction houses' reputation allows them to attract higher quality lots or because they actually do a better job at certifying and marketing their merchandise. The percentage price changes induced by the seller characteristics range from 32\% (sold by Christie's London) to 63\% (sold by Sotheby's New York). ${ }^{26}$ Special copies sold from well-known collections increase the price, ceteris paribus, by $54 \%$ and signed copies by $116 \%$. Condition as measured by the employed four-scale classification has also a very sizable estimated price impact of $49 \%$ per category, implying that fine copy (category 4) costs about 2.5 times the price of an otherwise similar poor copy (category 1). The estimates (not shown) of almost all of the title specific covariates have the expected positive sign and are statistically and numerically significant. ${ }^{27}$

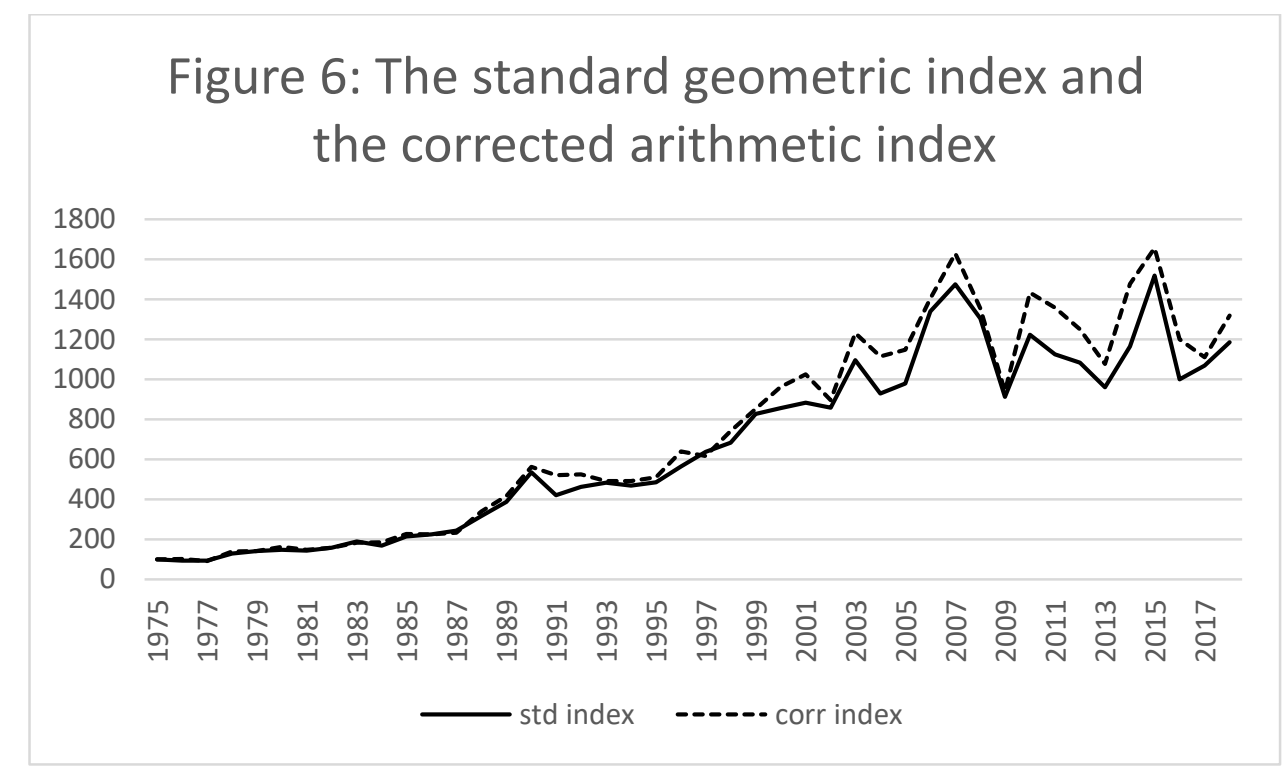

\footnotetext{
${ }^{26}$ The price fetched when selling in a UK auction house other than Christie's and Sotheby's is estimated to be $2 \%$ less than the price fetched when selling the very same book in a US auction house other than Christie's and Sotheby's. But this relative price difference is not statistically significant.

${ }^{27}$ Interpreting the estimated title effects is not straight forward because it is not clear which issues are supposed to be compared if a first edition comes in different versions.
} 
The estimates of the year dummy coefficients are reported in Table A1 of the Appendix together with the respective standard deviations, the standard index $I$, the corrected index $I^{c}$, and the resulting annual returns. The standard index $I$ and the corrected index $I^{c}$ are depicted in Figure 6. Given the relatively small annual sample sizes, it is not surprising that the reported index values have relatively low statistical precision as measured by the reported standard deviations. In any event, the two indices indicate a relatively continuous annual price increase up to the year 2007 (on average 8.8\% when measured with the standard index and 9.1\% with the corrected index), followed by more volatility and a negative trend afterwards ($2.0 \%$ and $-1.9 \%)$. Over the entire observation period 1975-2018, the average annual price increase amounted to $5.9 \%$ according the standard index and $6.2 \%$ according to the corrected index.

\section{Table 3 at the end of the paper}

Pooling the observations of all 25 titles also allows to examine the conjecture that books written by British (American) authors fetch higher prices when sold by British (American) auction houses. Fifteen of the 25 Fadiman-sample authors are British, eight American, and two neither (James Joyce was Irish and Joseph Conrad was born in that part of the former Polish-Lithuanian Commonwealth that became Russian after the third partition of Poland in 1795; Conrad was thus formally a Russian subject until he obtained British citizenship in 1886 at the age of 29 . In my sample, $57.5 \%$ of the auctioned books were written by British and $30.8 \%$ by American authors (11.7\% by Conrad and Joyce). British auction houses handled a somewhat larger share of books by British authors, Conrad, and Joyce (about 43\%) than indicated by their overall transaction volume of about one third; American auction houses, on the other hand, handled the lion's share of books written by Americans (about 93\%). ${ }^{28}$ To test the hypothesis the location of the auction house (UK or US) is interacted with the nationality of the respective author (UK_Author=1 for UK nationals and 0 otherwise, and likewise for UK_Author). The estimated coefficients (results not shown) indicate that books by British authors fetch in Britain on average $20 \%$ more than in America (statistical significance at the $95 \%$ (evel); books by American authors, however, do not fetch significantly higher prices in America than in Britain.

\footnotetext{
${ }^{28}$ See Table $A 2$ in the Appendix.
} 


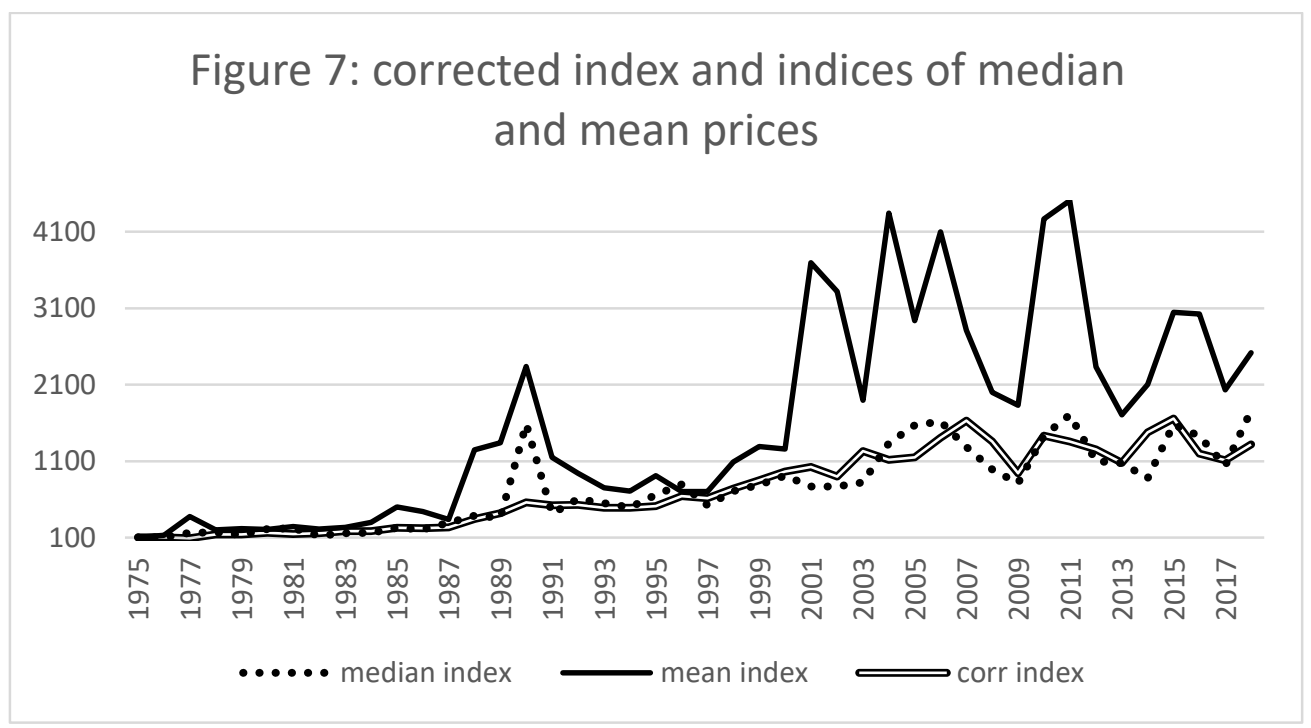

Figure 7 compares the corrected (nominal) price index with indices of mean and median nominal prices. The figure shows that the mean-price index almost always overestimates the price level and also price volatility, whereas the median-price index is more in tune with the corrected index but also overestimates price volatility. Simple price indices based solely on median or mean prices, i.e. price indices that do not control for the features of the auctioned books, thus do not suffice to arrive at a reasonable evaluation of the price development in this market, indicating that price indices based on hedonic regressions provide a substantial value added to our understanding of rare book price formation.

\subsection{Robustness checks}

I check the robustness of the standard baseline index (as estimated in column 2 of Table 3, detailed in Table A1 of the Appendix, and illustrated in Figure 5) in three ways. First, I examine how the standard baseline index reacts to the omission of covariates. In a second step, I investigate whether using title-specific condition indices influences the resulting price index. A last robustness test concerns the estimation technique.

In the regressions reported in columns (3)-(6) of Table 3, some groups of covariates included in the baseline regression (column 2) are omitted. In the regression reported in column 3 only the title fixed effects are retained which yields an $R^{2}$ of a mere $51 \% .{ }^{29}$ Adding the seller specific variables (column 4 ) increases the adjusted $R^{2}$ by 9 percentage points.

\footnotetext{
${ }^{29}$ Notice, that $\mathrm{R}^{2}$, the coefficient of determination, is a crucial feature in index construction while it plays a secondary role when testing or measuring the effect of certain variables on some (dependent) variable of interest.
} 
Adding the group of variables that describe title specifics, such as binding or issue variants, results in another decrease of the unexplained price variation by 12 percentage points, whereas the additional inclusion of the two employed provenance indicators (column 6) reduce the unexplained variation by an additional 4 percentage points, yielding an $R^{2}$ of $75 \%$. By including the condition index, as documented by the baseline regression (2), one can reduce the unobserved variance by another 4 percentage points and arrives at an adjusted $\mathrm{R}^{2}$ of $80 \%$.

Instead of relying on the $\mathrm{R}^{2}$ statistic, one can test how much the various groups of covariates influence the standard baseline index by directly comparing the indices that are obtained by omitting those groups at a time (regression outputs not shown). Figure 8 plots the resulting indices together with the baseline index. Interestingly, omitting the condition variable has a smaller effect on the estimated price index than the omission of the other groups of covariates. This insight is important because coding condition is a time consuming endeavor fraught with problems deriving from potentially biased information provided by the auction houses and from biases introduced, perhaps unwittingly, in the always subjective business of coding. Simpler procedures of estimating price indices, i.e. procedures that rely on fewer but more easily available objective hedonic variables, are therefore not necessarily inferior to indices derived using the whole works of conceivable variables. ${ }^{30}$

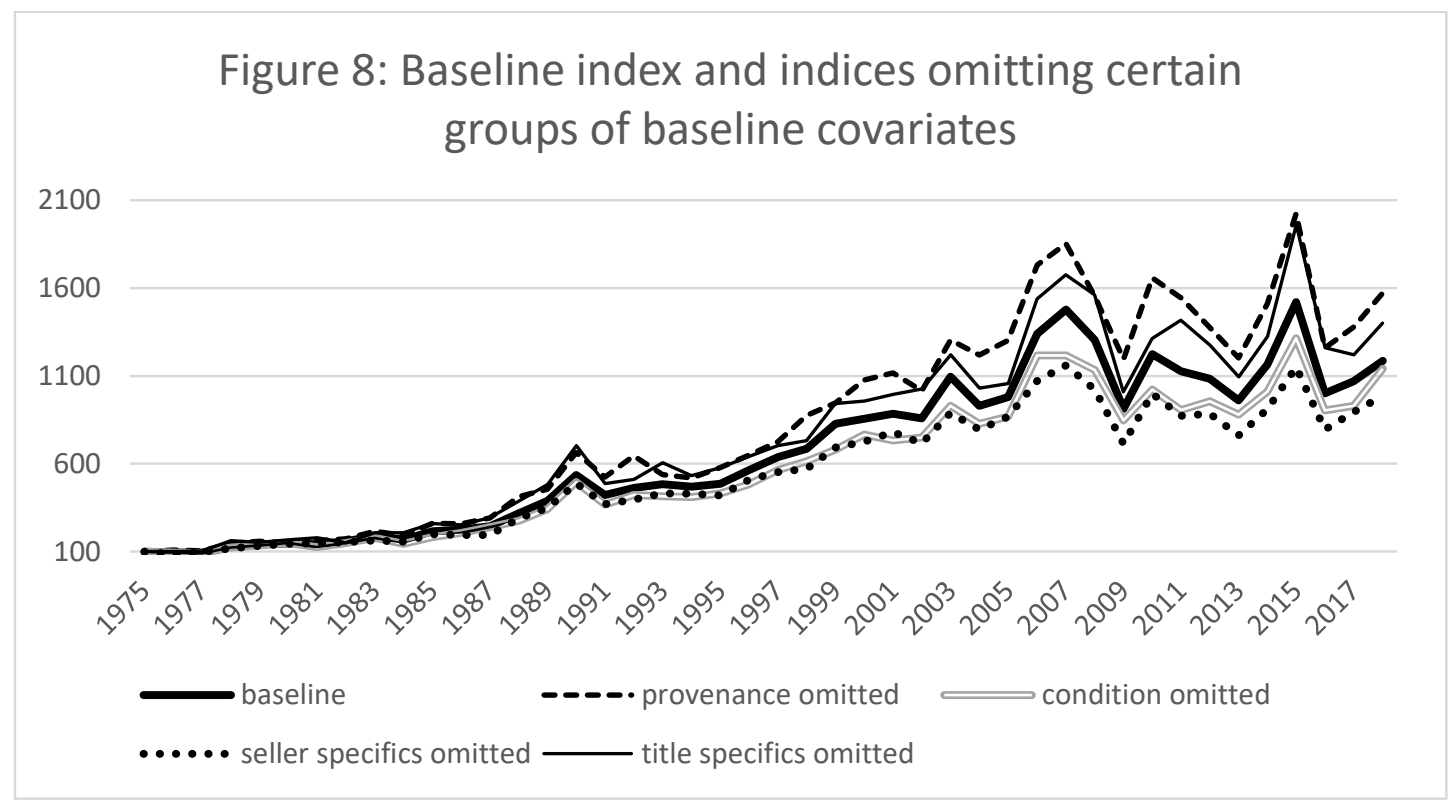

\footnotetext{
${ }^{30}$ Charlin and Cifuentes (2014) propose in the context of art-price metrics an even more extreme approach which, as they argue, may be applied when assessing artwork as purely financial assets.
} 
One may, of course, distrust the rather small estimated contribution of book condition on the baseline Index because the baseline specification presumes that the condition index has the same influence on all titles included in the index. Why, for example, should the condition of a $17^{\text {th }}$ century edition of Pilgrim's Progress have the same influence on its price as the condition of a first edition published in the middle of the $20^{\text {th }}$ century, such as Brave New World? To examine this kind of heterogeneity, I substituted the condition index with the 25 title $^{*}$ condition interaction variables. The coefficient estimates of these interaction variables do not show any discernable pattern relating, for example, to the age of the respective books, but substantial variance. ${ }^{31}$ Most importantly, this change in specification has no noticeable effect on the estimates of the price index.

The specification of the baseline regression model (3) assumes, moreover, that the effect of the hedonic variables on prices does not change across the observation period of almost half a century. Given the changes in the literary canon (or even the abandoning of the very concept of a literary canon), this is a rather heroic assumption. It is therefore worthwhile to consider a more flexible estimation approach, the so-called adjacent period model, that allows the hedonic coefficients to change over time. The adjacent period model calls for estimating price changes for all overlapping pairs of periods; the price index is then computed by chain-linking the obtained rates of price changes. ${ }^{32}$ The periods need to be chosen as short as possible to make changes in preferences unlikely, and long enough to arrive in each period at a sufficient number of observations to allow for a satisfactory estimate the coefficients. Given the rather small number of annual sales (see Figure 5, panel 1), I had to settle for fouryears periods. Comparing the resulting adjacent period index with the standard price index arrived at by averaging the annual index values for the respective four-years periods, Figure 9 shows that the two indices only began to differ in the last 15 years, and those observed difference are small.

\footnotetext{
${ }^{31} 19$ of the 25 estimates of the interaction terms are positive and different from zero at the $1 \%$ level of statistical significance, 3 at 5\%, 2 at 10\%, and one (Ambassadors) is statistically not different from zero.

32 To be more precise, the regression for the first period pair (in my case 1975-1982) is specified exactly as the baseline specification (3) with the exception that the year dummies are replaced by one dummy variable that assume the value 1 for the observations in period 1979-1982, and 0 otherwise. The estimate of the coefficient of this dummy variable is then used to compute the estimated rate of the price change from 1975-1978 to 19791982. To arrive at the index running up to the last period 2015-2018, this process is repeated for the period 1979 1986 etc. and by chain linking the obtained estimated rates of price changes.
} 


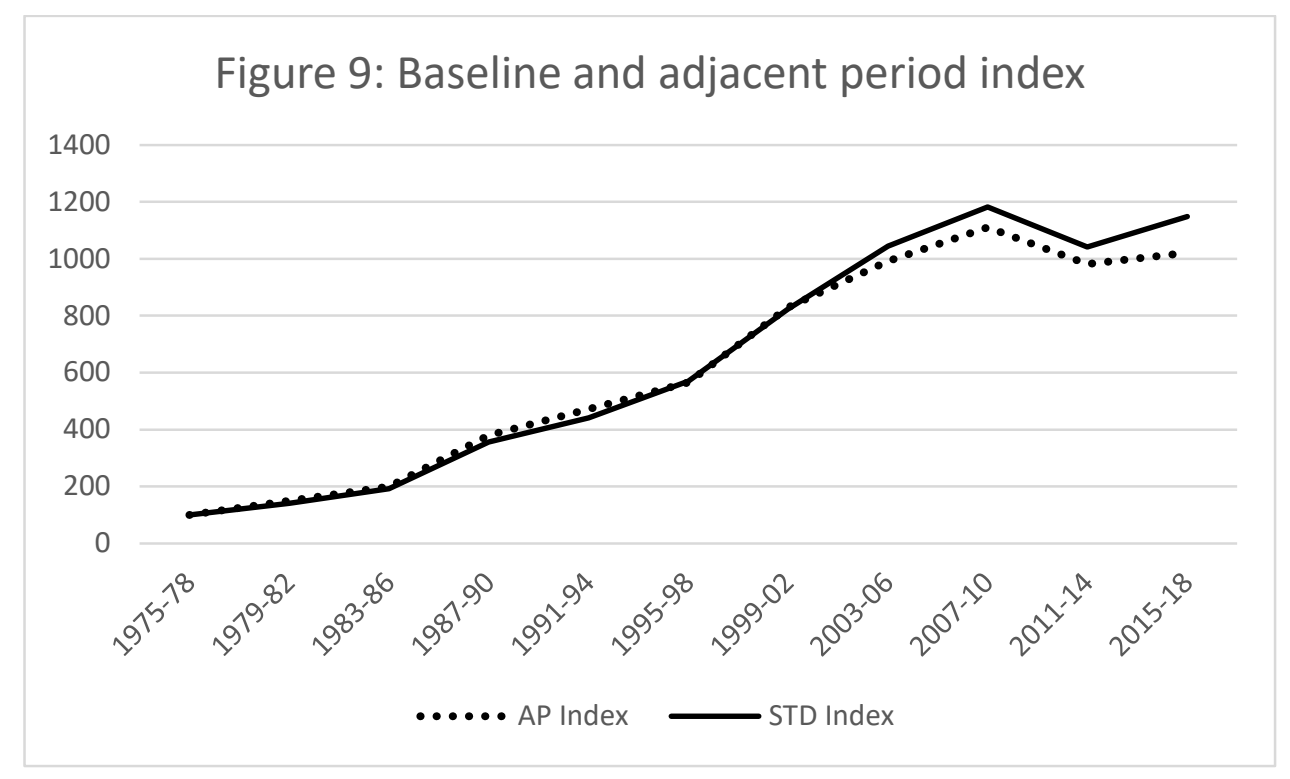

\subsection{Three extensions: Period, quantile, and collection indices}

The rare books in the Fadiman sample appeared in the 18th, 19th, and the first half of the 20th century. It therefore seems natural to estimate in a first extension of the baseline model the price development of these three categories of books separately. The period-ofpublication indices are plotted in Figure 10 together with the baseline index (regression results not shown). Beginning in the 1990s, books of 20th century authors have become substantially dearer than books written in the two earlier centuries. But this superior financial performance comes at the price of a higher volatility of returns. This result is well in line with what is known from the visual art market. Renneboog and Spaenjers (2013), for example, find that post-war art outperformed between 1982 and 2007 works of earlier genres, albeit at a higher volatility.

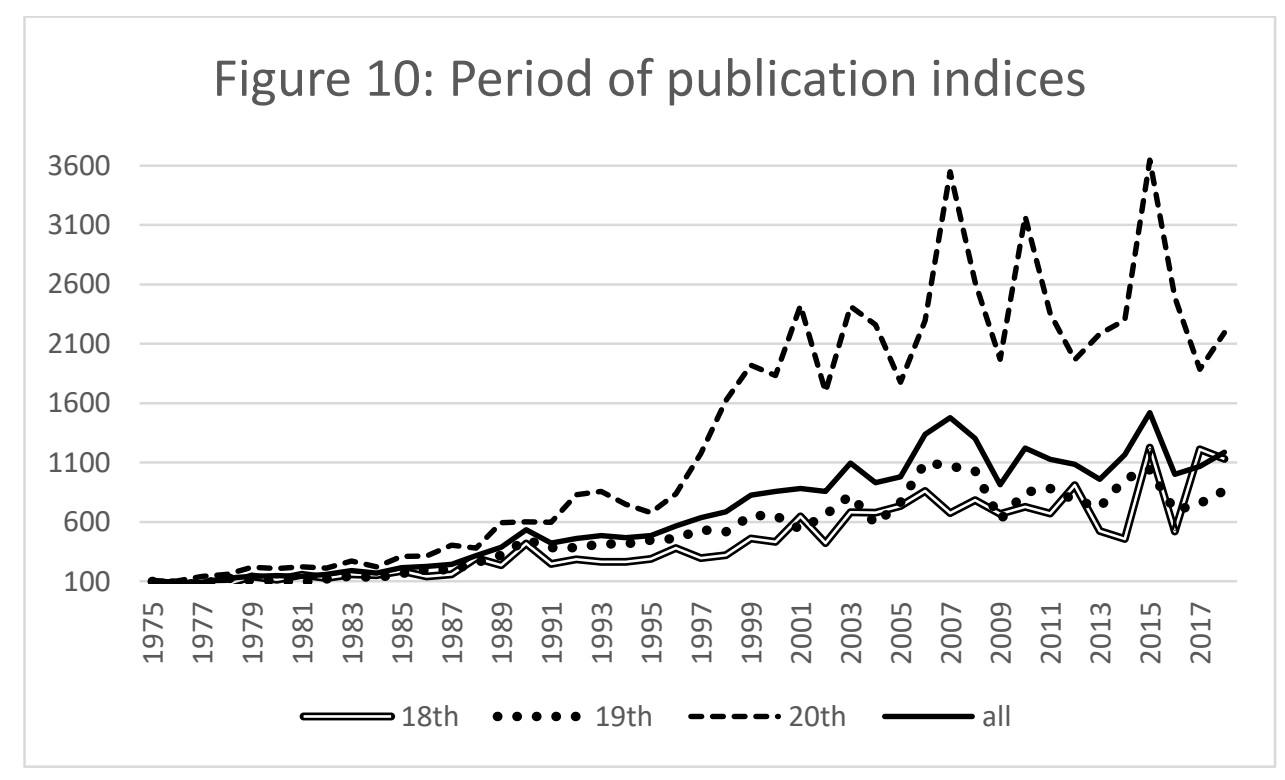


A second extension explores the price changes in different price tiers by dividing the sample into price quartiles. Figure 11 plots indices of the raw nominal prices for the $25^{\text {th }}, 50^{\text {th }}$ (median), and $75^{\text {th }}$ percentiles. In the long run, no systematic differences are noticeable, but in boom periods, medium and higher priced book usually do better than lower priced books. As a consequence, price volatility varies positively with price tiers. It is of course possible that ceteris-paribus differences in price changes across price tiers actually exist but are camouflaged by taking simple averages of raw prices. To test for such differences across price tiers one has to relate to normalized prices, i.e. prices corrected with the help of quantile regressions for the effect of the covariates included in the baseline hedonic regression.

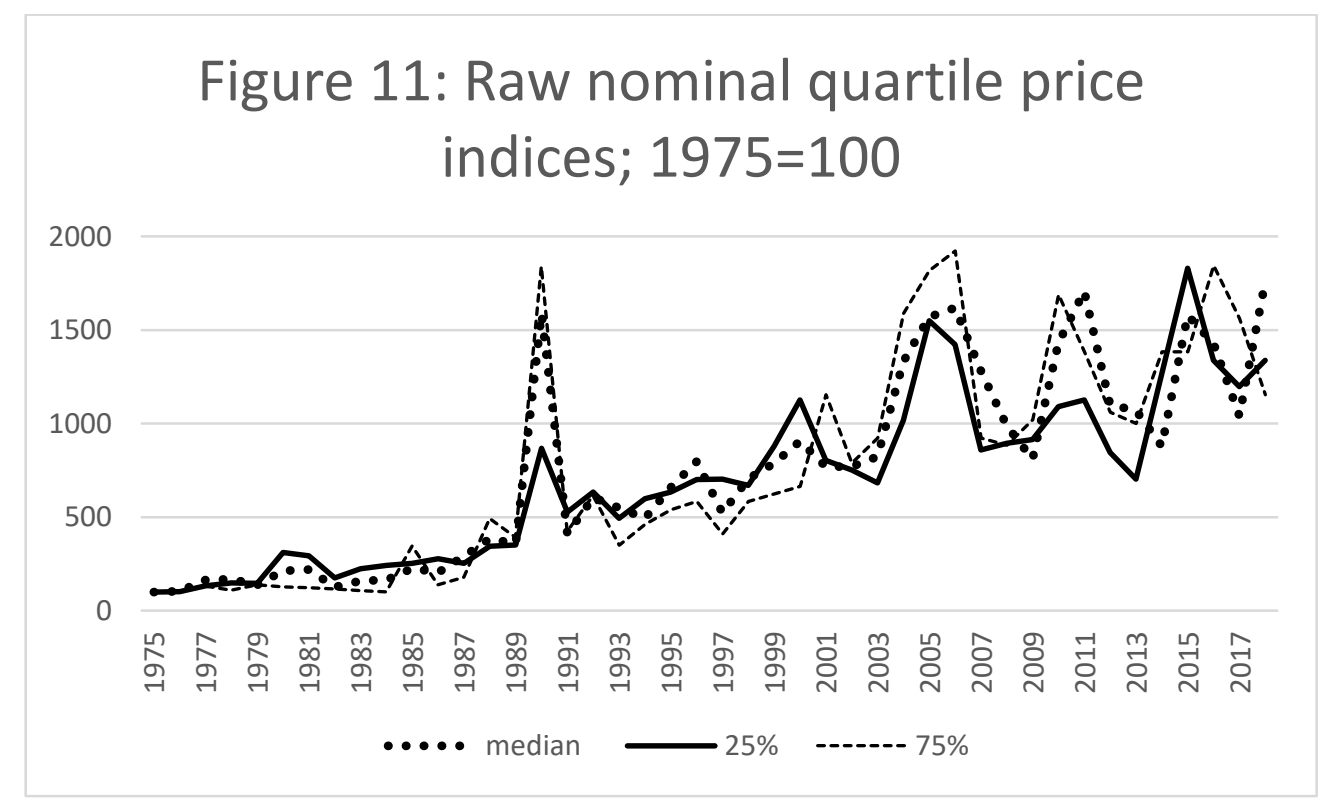

For quantile regressions to identify price differences within and not between periods, the adjacent-period regression approach needs to be applied again, this time, however, implemented for quantile regressions. The resulting price indices are plotted in Figure 12 for the $25^{\text {th }}, 50^{\text {th }}$ (median), and $75^{\text {th }}$ percentiles. The result confirms the impression conveyed by the raw price data depicted in Figure 11: the price developments between the three price tiers do not greatly differ even if the prices are corrected for the influence of the hedonic characteristics. If anything, the prices of relatively cheap rare books increased up to 2007 more than the prices of more pretentious copies. This is a quite remarkable result since in the art 
market prices increased in a similar period much more for expensive pieces of art than for low-priced pieces (Renneboog and Spaenjers 2013). ${ }^{33}$

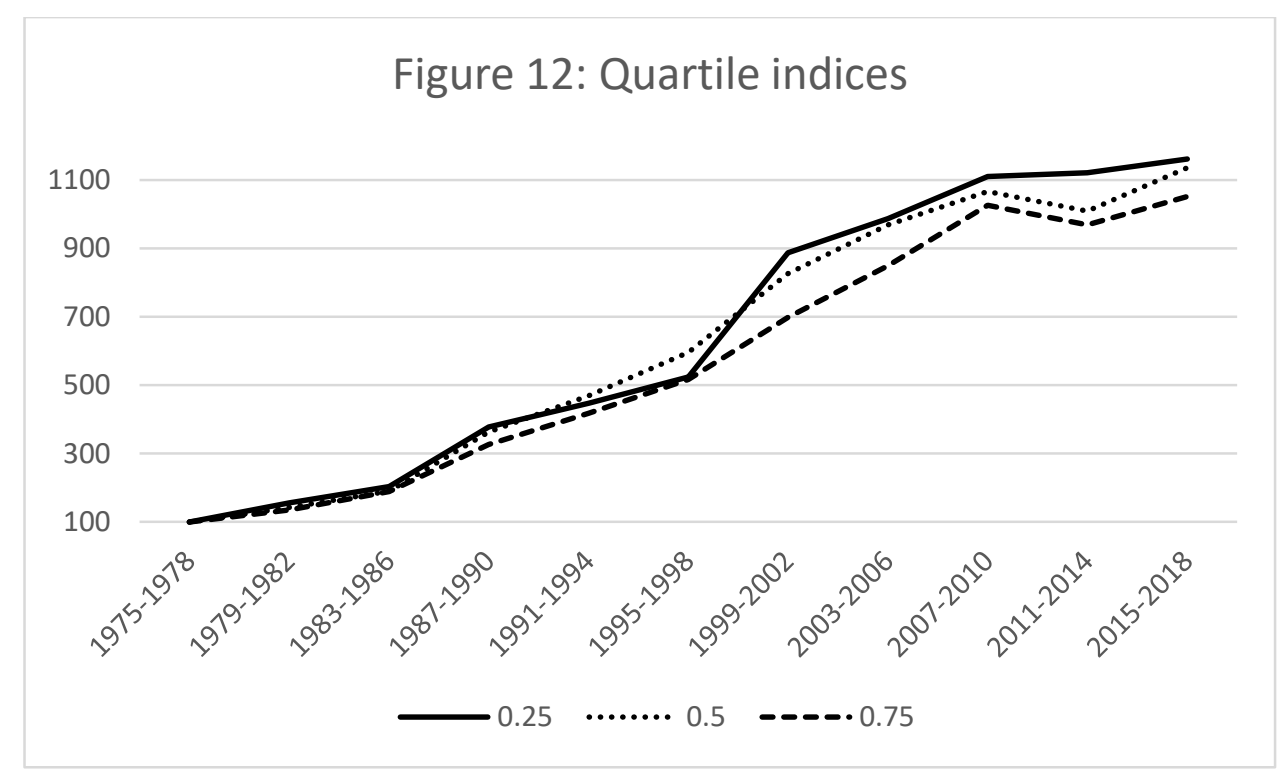

A last extension of the baseline index shows how the market price of a collection would have developed had a collector taken Fadiman's lifetime reading plan as an inspiration to buy a first edition of each recommended book. All book collections are built after an idiosyncratic plan. Unlike the fictitious Fadiman 1960 collection, the idea behind the composition of book collections escapes, however, quite often the comprehension of the observer. In any event, these collection plans always call for including very specific items that will never conform to the pattern of auction sales which trace the bibliophile community's aggregate behavior. Price indices that attach the same weight to each transaction, therefore do not reflect the financial returns to specific collections. The baseline index developed in section 4 is, for example, heavily influenced by the titles that are most often auctioned, i.e. by the Pickwick Papers, Huckleberry Finn, and Ulysses which, together, account for about $38 \%$ of the observations.

I therefore also constructed an index that gives each of the 25 titles the same weight in the hedonic regression by weighting each observation with the inverse of the share of the respective title in the entire sample. The resulting "collection index" shows that the Fadiman 1960 collection appreciated a little more than the baseline index indicates. Because of the

\footnotetext{
${ }^{33}$ This difference between the art and the rare book market may derive from art collectors being more likely to buy especially expensive pieces of art to signal their high incomes. This conjecture is in line with the finding by Goetzmann et al. (2011) that the income of the top 0.1 percent income earners has a significant impact on art prices.
} 
increased heterogeneity of the included items, the collection index is, however, more volatile than the baseline index. ${ }^{34}$

\section{ARE RARE BOOKS A REASONABLE INVESTMENT?}

Using the consumer price index of the United States, I converted the standard and the corrected nominal price indices into real indices and arrived for the period 1975-2018 at a real (compound) annual return of $2.19 \%$ for the standard index, and $2.45 \%$ for the corrected index. Figure 13 reveals that these figures conceal an extraordinary variability of annual real returns, ranging for the corrected index from $-30 \%$ to $+51 \%$; in larger samples, annual returns would, of course, be less affected by outliers. A second insight from this figure is that many of the negative annual returns may well be caused by expected or actual downturns of the business cycle. The years that can be associated with expected or actual recessions in the US or the UK are indicated in Figure 13 with black bars.

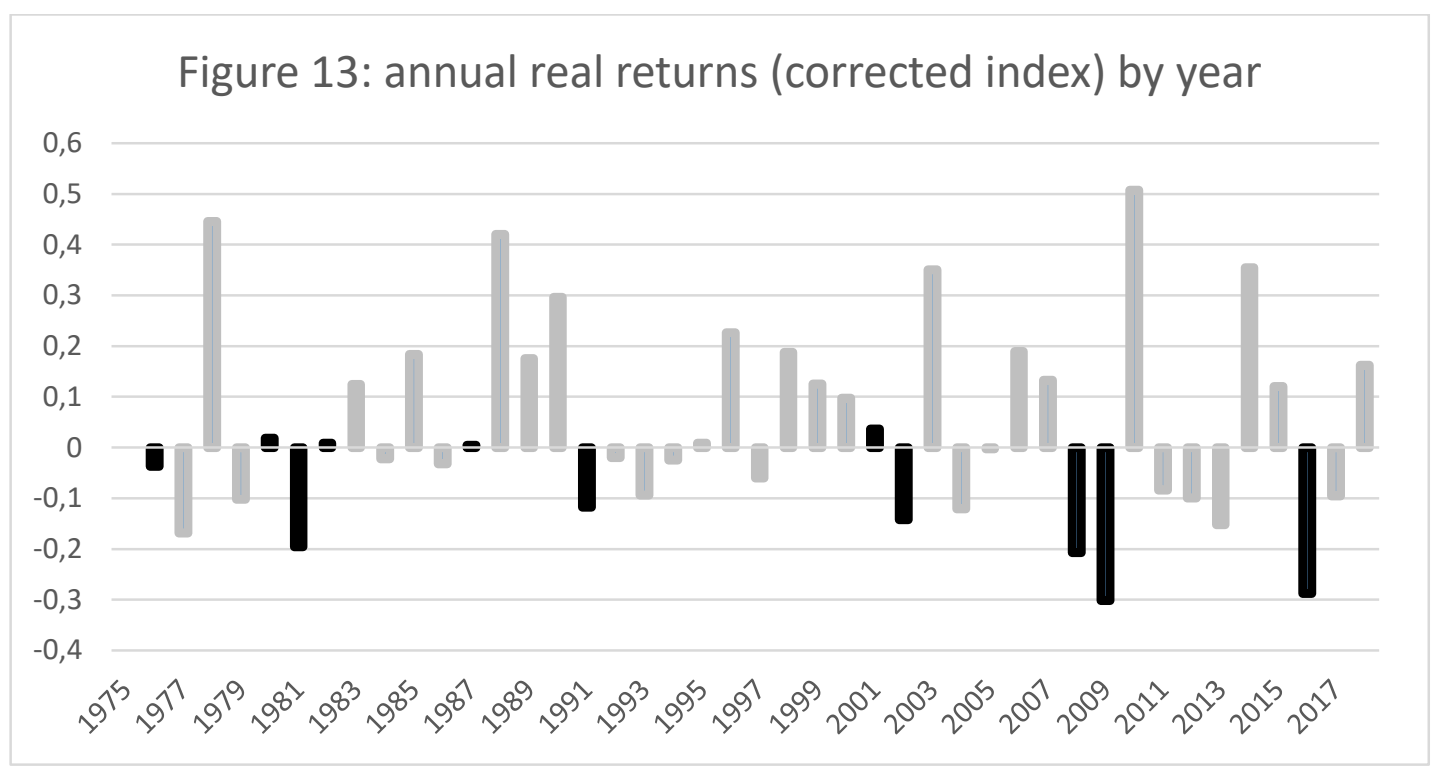

To be sure, collectors, if they do care about financial returns at all, are primarily interested in the long-run. But even long-run returns may be greatly affected by the annual price variability because returns heavily depend on the choice of the cutoff dates. Baring this caveat in mind, Table 4 reports the real compound annual returns on rare books for the entire observation period and for the sub periods 1975-2007 and 2007-2018. It transpires that the overall price development can be decomposed in a period of healthy price increases up to the great

\footnotetext{
${ }^{34}$ The respective returns are reported in Table 4.
} 
recession of $2008 / 09$, followed by a period of falling prices. Given the fairly constant consumer price inflation over the entire observation period, one already would have suspected this break in the price trend from the nominal price indices depicted in Figure 6.

Table 4: Comparing real returns on various investments

\begin{tabular}{|c|c|c|c|}
\hline & $\begin{array}{l}1975-2018 \\
43(40) \text { years }\end{array}$ & $\begin{array}{l}1975-2007 \\
32 \text { years }\end{array}$ & $\begin{array}{l}2007-2018 \\
11 \text { years }\end{array}$ \\
\hline $\begin{array}{l}\text { Rare Books } \\
\text { standard } \\
\text { weighted } \\
18^{\text {th }} \text { century } \\
19^{\text {th }} \text { century } \\
20^{\text {th }} \text { century } \\
\text { adjacent period } \\
25^{\text {th }} \text { percentile } \\
50 \% \text { percentile } \\
75^{\text {th }} \text { percentile } \\
\text { corrected }\end{array}$ & 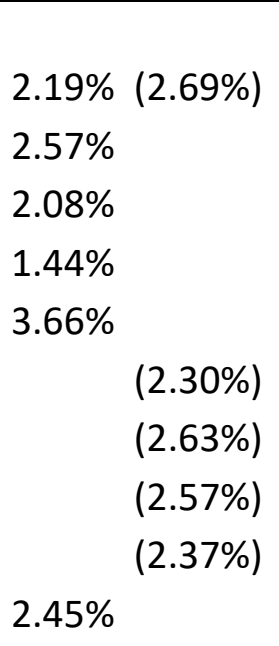 & $\begin{array}{l}4.29 \% \\
5.68 \% \\
1.77 \% \\
3.25 \% \\
7.19 \%\end{array}$ & $\begin{array}{l}-3.67 \% \\
-5.98 \% \\
2.97 \% \\
-3.65 \% \\
-5.94 \%\end{array}$ \\
\hline $\begin{array}{l}\text { Art } \\
\text { original RS index (corrected) }{ }^{35} \\
\text { updated RS index }{ }^{36} \\
\text { artprice.com index }\end{array}$ & $-0.61 \% *$ & $\begin{array}{l}3.26 \% \\
1.55 \%\end{array}$ & $\begin{array}{l}-7.91 \% * \\
-4.16 \%\end{array}$ \\
\hline Gold $^{38}$ & $1.24 \%$ & $0.04 \%$ & $3.83 \%$ \\
\hline Real estate (BIS, US) & $0.91 \%$ & $1.56 \%$ & $-0.94 \%$ \\
\hline 10-year T-bonds (Damodaran) & $3.26 \%$ & $3.80 \%$ & $1.71 \%$ \\
\hline Stocks (Shiller) & $7.26 \%$ & $7.95 \%$ & $5.29 \%$ \\
\hline
\end{tabular}

Note: Entries in brackets indicate estimates based on adjacent four-year period regressions.

*) period up to 2016 , not 2018 !

In Table 4, the financial performance of investing in rare books is compared with the financial performance of investments in art, gold, real estate, and financial assets. The first

\footnotetext{
${ }^{35}$ Renneboog and Spaenjers (2013)

${ }^{36}$ Personal communication

${ }^{37}$ http://imgpublic.artprice.com/pdf/agi.xls

${ }^{38}$ https://www.macrotrends.net/1333/historical-gold-prices-100-year-chart (inflation adjusted)
} 
estimate of real returns in the art market for the period 1975-2007 is taken from Renneboog and Spaenjers (2013) who have collected a sample of over 10,000 artists and more than a million observations. They estimate the compound annual return of art prices at $3.97 \%$ for the period $1957-2007,3.26 \%$ for the period $1975-2007$, and $5.19 \%$ for the period $1982-2007$. Those estimates appear rather modest in comparison to some earlier, but less reliable, estimates. Even though these estimates are, from a methodological point of view, easily comparable with my estimates for rare books, the precision of the estimates for the art market is, of course, much higher because they are derived from a much larger sample. The return difference between the two classes of collectibles therefore need not be statistically significant. It is, nevertheless, remarkable that returns in the rare book market turn out to be larger than the returns in the art market. For the 1975-2007 period, the difference amounts to $1.0 \%$ (standard index) and $1.35 \%$ (corrected index). The last year in this art market sample (2007) marks, of course, the peak of the rare book price indices, thus giving rise to surmising that re-estimating the art market returns with data that include the years after 2007 might produce quite different results. Indeed, an update of the Renneboog and Spaenjers (2013) index for the years up to 2016 implies not only decreasing returns after the peak year 2007 but also markedly smaller returns for the periods $1975-2007 .{ }^{39}$ In the last row, I report the compound annual return for the years 2007-2018 estimated with the help of the price index provided by Artmarket.com. The estimate of an annual loss of $4.16 \%$ is somewhat smaller than the annual loss of 7.91 indicated by the updated Renneboog and Spaenjers (2013) index, but still larger than the estimated annual loss of 3.6\% from investing in rare books.

Compared with gold and real estate (existing one-family houses in the US, BIS data), rare books appear to be reasonable investments, at least if one considers the long haul and neglects transaction costs which may be significantly higher for collectibles than for buying and selling a house in the US, not to speak of the bid-ask spread in the gold market. Selling rare books in periods of economic uncertainty may, however, not be a good idea as indicated by the high volatility and sideways trend of rare book prices after the great recession.

Financial assets do, of course, outperform collectibles almost by definition when it comes to financial returns because holding financial assets does not provide any consumption value and is not suited for signaling financial, social, or intellectual status. In the long run, 10year treasury bonds do not appear to do very much better than collectibles, but all types of

\footnotetext{
${ }^{39}$ I received the updated price index by personal communication.
} 
bonds certainly outperform collectibles in terms of risk, i.e. lack of volatility (Renneboog and Spaenjers 2013, Table 5). Stocks are more volatile than bonds, do however compensate this extra risk with the highest returns of all assets in the long run.

It is this feature of excelling in long-run financial performance that makes stocks the prime candidate for serving as a measuring rod of the different types of returns on collectibles that are, as a rule, bought and hold for a lifetime. If one accepts this argument, the difference between the returns on stocks and the financial returns on collectibles simply measures the non-pecuniary returns accruing to a collector from holding his or her favorite kind of collectibles. These non-pecuniary returns are almost always positive; negative non-pecuniary returns have only been observed for relatively short periods (Burton and Jacobson 1999). In the case of rare books, these non-pecuniary returns range from $4.8 \%$ in the entire observation period $1975-2018$ (the financial real returns on rare books and stocks amounting to $2.45 \%$ and $7.26 \%$ ), to $8.9 \%$ in the post great-recession period 2007-2018 (see Figure 14).

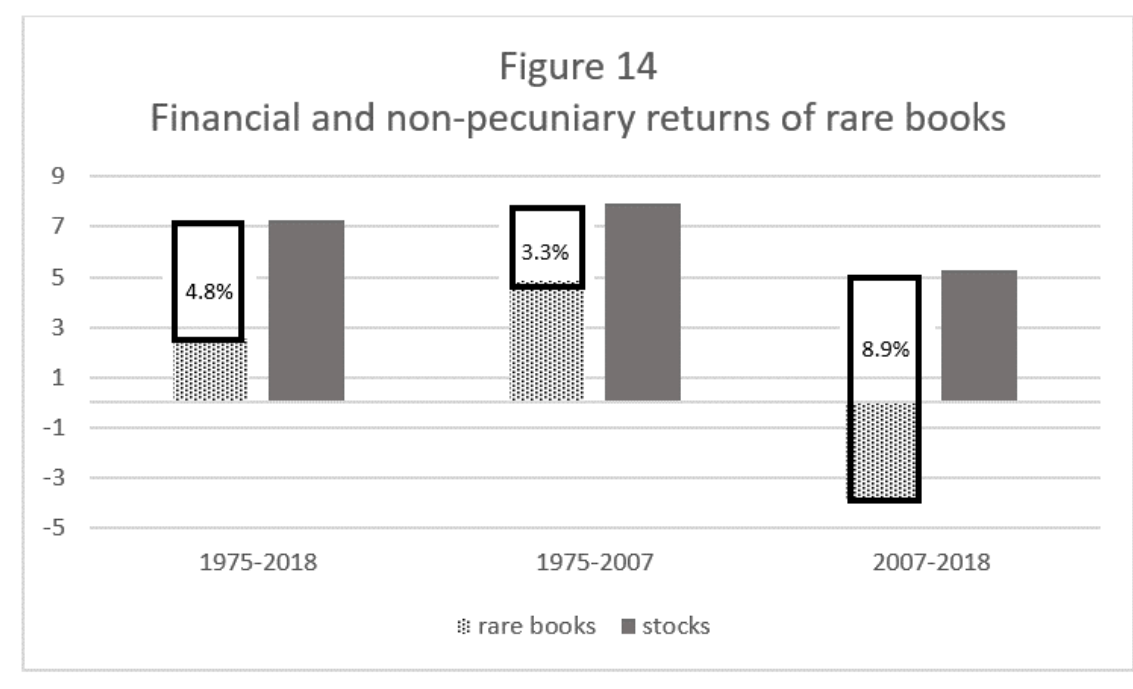

The question remains as to what non-pecuniary returns of collectables might reflect. The consumptive value probably springs to mind first, i.e. the value accruing to the holder of collectibles from having the privilege of enjoying the use of the collection. Collectibles are, however, also used for non-consumptive reasons. The collector might, for example, display the collection for purely expressive reasons, i.e. to signal his cultivated personality, socioeconomic status (Mandel 2009), or other aspects of his assumed identity to whoever he chooses to let know about his collection. A second potential behavioral reason transcends the neoclassical economic model of behavior by doing away with the assumption of deeply-rooted 
stable preferences (Becker and Stigler 1977) and proposes that desires are influenced by mimetic behavior and thus change as we go. Mimetic theory, developed by the anthropological philosopher René Girard (1961), if translated into economic terms, basically maintains that preferences always have a mimetic character; they do not reflect a deeply rooted individuality but are rather incited by the desires of other persons. They are in particular transformed by envy and jealousy and thus ever malleable. This preference-based explanation of non-pecuniary returns is probably best able to portray the addictive behavior of many collectors, the so-called collecting mania or, in the case of book collecting, bibliomania.

\section{DISCUSSION}

Investigating the diverse markets for collectables is for at least two reasons a valuable endeavor. First, the size of those markets is often substantial; they therefore deserve the attention they have received so far. Second, it is well known by now that the financial investment performance of collectables is in all respects inferior to investments in traditional financial assets. It is, therefore, intriguing to explore why some people are prepared to pay exorbitant prices for things that appear to others quite worthless. To answer this question one needs to better understand the price formation in the various collectibles markets and the attainable financial returns in order to be able to compare the collectors' behavior across market segments. To add another facet to the economic literature on collectibles, I investigated in this study the price determinants and the long-run financial performance of collecting rare books.

I developed a hedonic regression approach to explaining rare book prices. The approach is applied to a sample of first editions of English fiction recommended for a lifetime reading in 1960 . The sample therefore only includes celebrated titles which every aspiring book collector would have been aware of even well before the beginning of my observation period 1975-2018. The sample size of 25 titles and some 3400 observations is admittedly rather small; but it serves well for an exploratory study that mainly aims at outlining an efficient way of constructing rare book price indices. An important insight gained from this exercise is that even though the physical condition of the collected books is of absolutely prime importance for the individual collector, book condition is not an imperative aspect when constructing rare book price indices because other hedonic variables which are much more 
easily available capture many aspects of book condition. Since coding book condition is a time consuming process, this is good news for everyone attempting to construct a rare book price index based on a much larger sample.

In the light of what can be learned from the economic and finance literature on collectibles, it is, of course, not surprising, that the results show that the investment performance of rare book collecting is significantly lower than the performance of traditional financial assets - and this comparison not even takes the substantial cost of auction transactions into account. ${ }^{40}$ On the other hand, investing in rare books, at least in the period for which methodologically similar estimates are available, appears to provide larger financial returns than investing in fine art. ${ }^{41}$ And, as compared to studies on price formation and financial returns in the art market, I do not find that the high-end market segment yields higher financial returns than a portfolio of medium or low-priced rare books. Despite the similarities between the rare-book and fine-arts markets, the two collectibles markets thus appear to be governed by somewhat different behavioral patterns of the market participants. To identify and explain these distinctive behavioral modes of collectors of different collectibles remains an interesting and open field of behavioral cultural economics. My hunch is that all collectors are alike in the sense that all of them do care little about the financial returns of their collections, but differ substantially in which kind of non-pecuniary returns they derive from their respective hobby-horse. For art collectors, the expressive returns may dominate, collectors of rare books may derive more consumption value from their collections than collectors of, say, walking canes, and victims of the modern-time mania of collecting sneakers are perhaps predominantly driven by mimetic impulses. Attempts to empirically discriminate between these three motives might, however, prove to be rather elusive.

\footnotetext{
${ }^{40}$ When assuming purely commercial motives of investing in rare books, one would also have to consider storing costs.

${ }^{41}$ I acknowledge that this comparison is predicated on the presumption that comparing my small sample of masterpiece fiction with fine art in general makes sense at all.
} 
Figure 5: Descriptive statistics
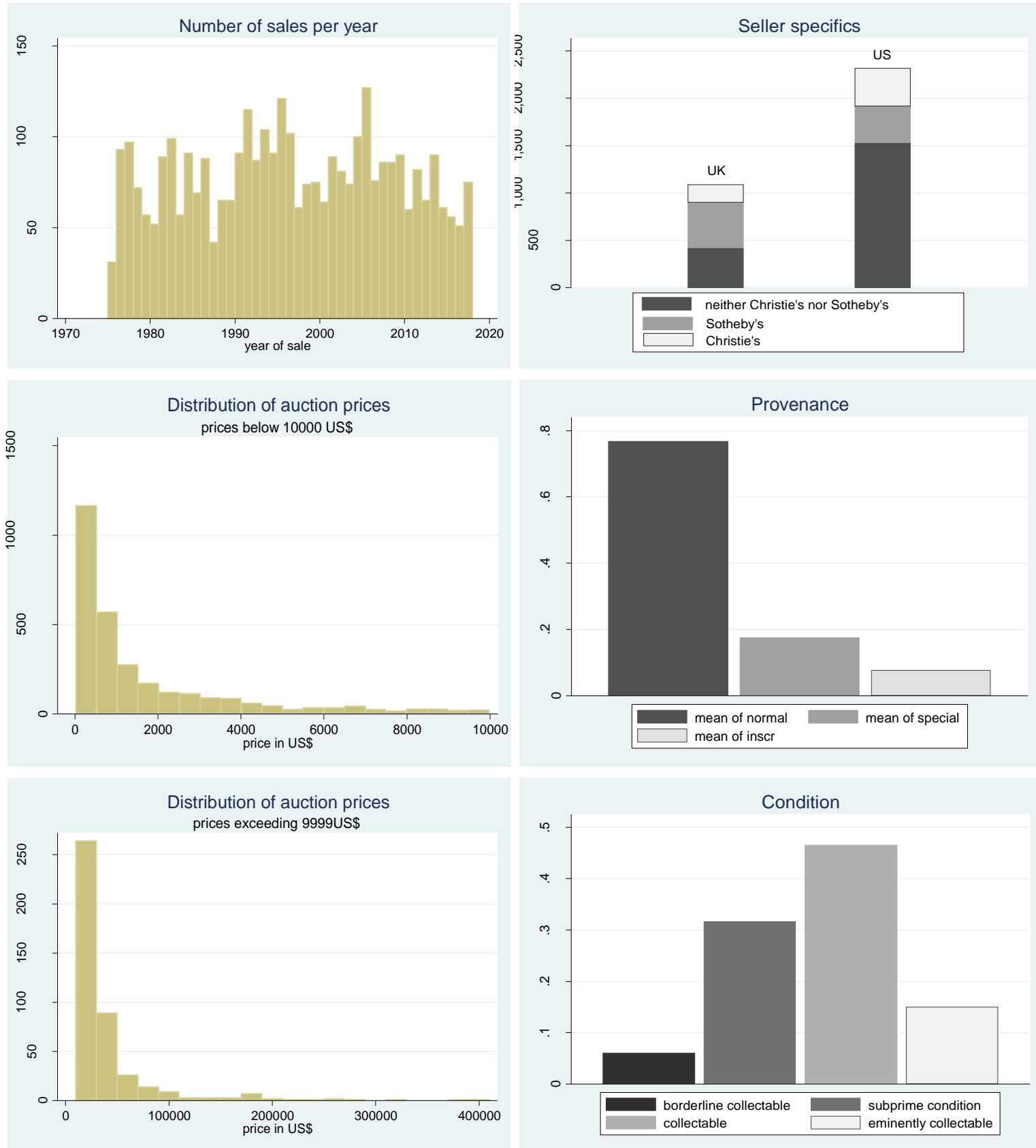
Table 1: OLS regressions, model (1), 363 observations.

Dependent Variable: ln of US dollar price of first edition Ulysses

\begin{tabular}{|c|c|c|c|c|c|c|c|}
\hline & $\begin{array}{c}\text { only } \\
\text { year of } \\
\text { sale } \\
(1) \\
\end{array}$ & $\begin{array}{c}\text { including } \\
\text { title } \\
\text { specifics } \\
(2)\end{array}$ & $\begin{array}{l}\text { all controls } \\
\text { without } \\
\text { condition } \\
(3) \\
\end{array}$ & $\begin{array}{c}\text { all } \\
\text { controls } \\
\text { condition } \\
\text { index } \\
(4)\end{array}$ & $\begin{array}{c}\text { all } \\
\text { controls } \\
\text { condition } \\
\text { dummies } \\
(5)\end{array}$ & $\begin{array}{c}\text { with } \\
\text { different } \\
\text { slopes } \\
(6)\end{array}$ & $\begin{array}{c}\text { with year } \\
\text { dummies } \\
\text { (not } \\
\text { shown) } \\
(7)\end{array}$ \\
\hline & $\begin{array}{c}0.085 * * * \\
(13.14)\end{array}$ & $\begin{array}{c}0.085 * * * \\
(22.68)\end{array}$ & $\begin{array}{l}0.083 * * * \\
(23.68)\end{array}$ & $\begin{array}{c}0.083 * * * \\
(28.63)\end{array}$ & $\begin{array}{l}0.082 * * * \\
(28.80)\end{array}$ & $\begin{array}{c}0.073 * * * \\
(16.26)\end{array}$ & \\
\hline Year* $1^{\text {st }}$ issue & & & & & & $\begin{array}{c}0.016 * * * \\
(2.76)\end{array}$ & \\
\hline
\end{tabular}

$\underline{\text { Title specifics }}$

One-of-100

$\begin{array}{clcccc}3.699 * * * & 3.323 * * * & 3.006 * * * & 2.994 * * * & 2.728 * * * & 2.946 * * * \\ (22.64) & (21.45) & (23.10) & (23.50) & (16.68) & (23.75) \\ & & & & & \\ 2.538 * * * & 2.281 * * * & 1.956 * * * & 1.971 * * * & 1.635 * * * & 1.935 * * * \\ (15.31) & (15.20) & (15.48) & (15.95) & (9.56) & (16.32) \\ 1.803 * * * & 1.634 * * * & 1.537 * * * & 1.558 & 1.222 * * * & 1.545 * * * \\ (18.93) & (18.77) & (21.29) & (22.03) & (9.06) & (22.20)\end{array}$

One-of-150

One-of-750

$\underline{\text { Seller specifics }}$

UK

$\begin{array}{lcccc}-0.205 & -0.131 & -0.169^{*} & -0.116 & -0.239^{* *} \\ (-1.63) & (-1.26) & (-1.65) & (-1.12) & (-0.32) \\ & & & & \\ -0.066 & -0.139 & -0.118 & -0.152 & -0.052 \\ (-0.33) & (-0.85) & (-0.73) & (-0.94) & (-0.45) \\ & & & & \\ 0.351^{* * *} & 0.175 & 0.182^{*} & 0.145 & 0.240^{* *} \\ (2.58) & (1.55) & (1.65) & (1.29) & (2.18) \\ & & & & \\ 0.297^{* *} & 0.041 & 0.010 & 0.042 & 0.057 \\ (2.14) & (0.36) & (0.08) & (0.37) & (0.41) \\ & & & & \\ 0.390^{* *} & 0.079 & 0.022 & 0.106 & 0.056 \\ (2.33) & (0.56) & (0.16) & (0.76) & (0.54)\end{array}$

Provenance

Special

$\begin{array}{lcccc}0.219 & 0.089 & 0.068 & 0.083 & 0.063 \\ (1.57) & (0.77) & (0.60) & (0.73) & (0.54) \\ 1.265^{* * *} & & & 1.169 * * * & 1.282^{* * *} \\ (7.05) & \begin{array}{c}1.196 * * * \\ (8.07)\end{array} & \begin{array}{c}1.159 * * * \\ (7.98)\end{array} & (7.94) & (9.07) \\ & & & & \end{array}$

Condition

Index

$0.598 * * *$

(12.87)

$0.588^{* * *} \quad 0.652 * * *$

Cond $=1$

$-1.169 * * *$

(12.74)

(14.54)

Cond $=2$

$(-7.67)$

$-0.303 * * *$

$(-3.56)$

Cond $=4$

$0.861 * * *$

constant

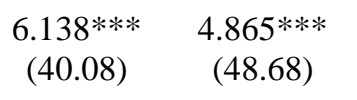

$4.860 * * *$

$3.295 * * *$

(9.89)

$5.012 * * * \quad 3.512 * * * \quad 2.756 * * *$

(47.15)

(22.20)

(57.66)

(21.05)

(9.56)

$\frac{\text { adj. R-squared }}{t \text { statistics in parentheses. }{ }^{*} p<0.10,{ }^{* *} p<0.05,{ }^{* * *} p<0.01}$ 
Table 2: OLS estimates of the time trends of all 25 titles

\begin{tabular}{|c|c|c|c|c|c|c|c|c|c|}
\hline & $\begin{array}{c}\text { Bunyan } \\
\text { Pilgrim’s } \\
\text { Progress } \\
1678\end{array}$ & $\begin{array}{l}\text { Defoe } \\
\text { Robinson } \\
\text { Crusoe } \\
1719\end{array}$ & $\begin{array}{c}\text { Swift } \\
\text { Gulliver } \\
1726\end{array}$ & $\begin{array}{c}\text { Fielding } \\
\text { Tom Jones } \\
1749\end{array}$ & $\begin{array}{c}\text { Sterne } \\
\text { Tristram } \\
\text { Shandy } \\
1759\end{array}$ & & $\begin{array}{l}\text { Austen } \\
\text { Pride and } \\
\text { Prejudice } \\
1813\end{array}$ & $\begin{array}{c}\text { Dickens } \\
\text { Pickwick } \\
\text { Papers } \\
1836 / 37\end{array}$ & $\begin{array}{l}\text { Poe } \\
\text { Tales } \\
1840 \\
1845\end{array}$ \\
\hline year of sale $(\hat{\delta})$ & $\begin{array}{l}0.098 * * * \\
(5.38)\end{array}$ & $\begin{array}{l}0.058 * * * \\
(4.13)\end{array}$ & $\begin{array}{l}0.071 * * * \\
(13.70)\end{array}$ & $\begin{array}{l}0.055^{* * * *} \\
(9.49)\end{array}$ & $\begin{array}{l}0.057 * * * \\
(7.38)\end{array}$ & & $\begin{array}{l}0.112 * * * \\
(12.34)\end{array}$ & $\begin{array}{l}0.055^{* * *} \\
(13.64)\end{array}$ & $\begin{array}{l}0.072 * * * \\
(6.75)\end{array}$ \\
\hline annual return (r) & $10.3 \%$ & $6.0 \%$ & $7.4 \%$ & $5.7 \%$ & $5.9 \%$ & & $11.9 \%$ & $5.7 \%$ & $7.46 \%$ \\
\hline $\begin{array}{l}\text { observations } \\
\text { adj. } R^{2}\end{array}$ & $\begin{array}{l}154 \\
0.76\end{array}$ & $\begin{array}{c}54 \\
0.58\end{array}$ & $\begin{array}{l}188 \\
0.75\end{array}$ & $\begin{array}{r}146 \\
0.64\end{array}$ & $\begin{array}{c}88 \\
0.63\end{array}$ & & $\begin{array}{c}79 \\
0.73\end{array}$ & $\begin{array}{l}383 \\
0.65\end{array}$ & $\begin{array}{c}77 \\
0.67\end{array}$ \\
\hline & $\begin{array}{c}\text { Bronte } \\
\text { Wuthering } \\
\text { Heights } \\
1847\end{array}$ & $\begin{array}{c}\text { Thackeray } \\
\text { Vanity Fair } \\
1848\end{array}$ & $\begin{array}{c}\text { Hawthorne } \\
\text { The Scarlet } \\
\text { Letter } \\
1850\end{array}$ & $\begin{array}{l}\text { Melville } \\
\text { Moby Dick } \\
1851\end{array}$ & $\begin{array}{c}\text { Eliot } \\
\text { Mill on the } \\
\text { Floss } \\
1860\end{array}$ & $\begin{array}{c}\text { Carroll } \\
\text { Alice in } \\
\text { Wonderland } \\
1866\end{array}$ & $\begin{array}{c}\text { Twain } \\
\text { Huckleberry } \\
\text { Finn } \\
1884 / 85\end{array}$ & $\begin{array}{c}\text { Hardy } \\
\text { Mayor of } \\
\text { Casterbridge } \\
1886\end{array}$ & \\
\hline $\begin{array}{l}\text { year of sale }(\hat{\delta}) \\
\text { annual return }(\mathrm{r})\end{array}$ & $\begin{array}{l}0.101 * * * \\
(4.85) \\
10.6 \%\end{array}$ & $\begin{array}{l}0.045 * * * \\
(7.21) \\
4.6 \%\end{array}$ & $\begin{array}{l}0.061 * * * \\
(9.38) \\
6.3 \%\end{array}$ & $\begin{array}{l}0.070 * * * \\
(15.03) \\
7.3 \%\end{array}$ & $\begin{array}{c}0.056 * * * \\
(8.25) \\
5.8 \%\end{array}$ & $\begin{array}{c}0.081 * * * \\
(14.54) \\
8.4 \%\end{array}$ & $\begin{array}{l}0.056 * * * \\
(17.22) \\
5.8 \%\end{array}$ & $\begin{array}{c}0.074 * * * \\
(5.81) \\
7.7 \%\end{array}$ & \\
\hline $\begin{array}{l}\text { observations } \\
\operatorname{adj} . \mathrm{R}^{2}\end{array}$ & $\begin{array}{c}23 \\
0.89\end{array}$ & $\begin{array}{l}166 \\
0.64\end{array}$ & $\begin{array}{l}120 \\
0.66\end{array}$ & $\begin{array}{l}165 \\
0.74\end{array}$ & $\begin{array}{c}98 \\
0.56\end{array}$ & $\begin{array}{l}178 \\
0.59\end{array}$ & $\begin{array}{l}539 \\
0.66\end{array}$ & $\begin{array}{c}33 \\
0.76\end{array}$ & \\
\hline & $\begin{array}{c}\text { James } \\
\text { Ambassadors } \\
1903\end{array}$ & $\begin{array}{c}\text { Conrad } \\
\text { Nostromo } \\
1904\end{array}$ & $\begin{array}{l}\text { Lawrence } \\
\text { Sons and } \\
\text { Lovers } \\
1913\end{array}$ & $\begin{array}{l}\text { Maugham } \\
\text { Of Human } \\
\text { Bondage } \\
1915\end{array}$ & $\begin{array}{c}\text { Joyce } \\
\text { Ulysses } \\
1922\end{array}$ & $\begin{array}{c}\text { Forster } \\
\text { Passage to } \\
\text { India } \\
1924\end{array}$ & $\begin{array}{l}\text { Hemingway } \\
\text { In Our Time } \\
1924\end{array}$ & $\begin{array}{c}\text { Faulkner } \\
\text { Sound and Fury } \\
1929\end{array}$ & $\begin{array}{c}\text { Huxley } \\
\text { Brave New } \\
\text { World } \\
1931\end{array}$ \\
\hline $\begin{array}{l}\text { year of sale }(\hat{\delta}) \\
\text { annual return }(\mathrm{r})\end{array}$ & $\begin{array}{l}0.058 * * * \\
(4.92) \\
6.0 \%\end{array}$ & $\begin{array}{l}0.083 * * * \\
(6.67) \\
8.7 \%\end{array}$ & $\begin{array}{l}0.068 * * * \\
(5.31) \\
7.0 \%\end{array}$ & $\begin{array}{l}0.063 * * * \\
(6.05) \\
6.5 \%\end{array}$ & $\begin{array}{c}0.083 * * * \\
(28.63) \\
8.7 \%\end{array}$ & $\begin{array}{l}0.059 * * * \\
(10.52) \\
6.1 \%\end{array}$ & $\begin{array}{l}0.093 * * * \\
(5.78) \\
9.7 \%\end{array}$ & $\begin{array}{l}0.097 * * * \\
(9.71) \\
10.2 \%\end{array}$ & $\begin{array}{l}0.079 * * * \\
(14.27) \\
8.2 \%\end{array}$ \\
\hline $\begin{array}{l}\text { observations } \\
\text { adj. } \mathrm{R}^{2}\end{array}$ & $\begin{array}{c}34 \\
0.85\end{array}$ & $\begin{array}{c}35 \\
0.84\end{array}$ & $\begin{array}{c}34 \\
0.59\end{array}$ & $\begin{array}{c}49 \\
0.61\end{array}$ & $\begin{array}{l}363 \\
0.88\end{array}$ & $\begin{array}{c}99 \\
0.79\end{array}$ & $\begin{array}{c}38 \\
0.52\end{array}$ & $\begin{array}{c}76 \\
0.72\end{array}$ & $\begin{array}{l}183 \\
0.69\end{array}$ \\
\hline
\end{tabular}

Notes: *** Significant at 0.01 level. 
Table 3: OLS regressions, SE adjusted for 25 clusters (titles), 3402 observations. Dependent Variable: ln of US dollar price, all regressions include title fixed effects

\begin{tabular}{|c|c|c|c|c|c|c|}
\hline & $\begin{array}{c}\text { all } \\
\text { covariates } \\
\text { year of sale } \\
(1) \\
\end{array}$ & $\begin{array}{c}\text { all } \\
\text { covariates } \\
\text { baseline } \\
(2)\end{array}$ & 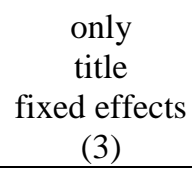 & $\begin{array}{l}\text { (3) plus } \\
\text { seller } \\
\text { specifics } \\
(4)\end{array}$ & $\begin{array}{l}\text { (4) plus } \\
\text { title } \\
\text { specifics } \\
(5)\end{array}$ & $\begin{array}{c}\text { (5) plus } \\
\text { provenance } \\
(6)\end{array}$ \\
\hline Year of sale dummies & no & yes & yes & yes & yes & yes \\
\hline Year of sale & $\begin{array}{l}0.067 * * * \\
(18.66)\end{array}$ & no & no & no & no & no \\
\hline$\underline{\text { Seller specifics }}$ & yes & yes & no & yes & yes & yes \\
\hline UK & $\begin{array}{l}0.042 \\
(0.77)\end{array}$ & $\begin{array}{l}-0.024 \\
(-0.43)\end{array}$ & & $\begin{array}{l}-0.120 \\
(-1.69)\end{array}$ & $\begin{array}{l}-0.075 \\
(-1.06)\end{array}$ & $\begin{array}{l}-0.042 \\
(-0.68)\end{array}$ \\
\hline Christie’s L & $\begin{array}{c}0.259 * * * \\
(3.26)\end{array}$ & $\begin{array}{c}0.324 * * * \\
(4.01)\end{array}$ & & $\begin{array}{c}0.764 * * * \\
(5.95)\end{array}$ & $\begin{array}{l}0.563 * * * * \\
(5.67)\end{array}$ & $\begin{array}{c}0.422 * * * \\
(5.15)\end{array}$ \\
\hline Sotheby's L & $\begin{array}{c}0.401 * * * \\
(4.95)\end{array}$ & $\begin{array}{c}0.497 * * * \\
(5.89)\end{array}$ & & $\begin{array}{c}0.896^{* * * *} \\
(9.11)\end{array}$ & $\begin{array}{l}0.721^{* * * *} \\
(7.58)\end{array}$ & $\begin{array}{c}0.598 * * * \\
(7.49)\end{array}$ \\
\hline Christie's NY & $\begin{array}{c}0.613 * * * \\
(6.48)\end{array}$ & $\begin{array}{c}0.566 * * * \\
(6.24)\end{array}$ & & $\begin{array}{c}1.274 * * * \\
(12.66)\end{array}$ & $\begin{array}{c}0.990 * * * \\
(8.75)\end{array}$ & $\begin{array}{c}0.709 * * * \\
(7.00)\end{array}$ \\
\hline Sotheby's NY & $\begin{array}{c}0.605 * * * \\
(7.82)\end{array}$ & $\begin{array}{c}0.628 * * * \\
(7.40)\end{array}$ & & $\begin{array}{c}1.411 * * * \\
(15.72)\end{array}$ & $\begin{array}{c}1.136 * * * \\
(10.67)\end{array}$ & $\begin{array}{c}0.729 * * * \\
(8.48)\end{array}$ \\
\hline$\underline{\text { Titles specifics }}$ & yes & yes & no & no & yes & yes \\
\hline Provenance & yes & yes & no & no & no & yes \\
\hline Special & $\begin{array}{c}0.550 * * * \\
(10.50)\end{array}$ & $\begin{array}{c}0.539 * * * \\
(9.98)\end{array}$ & & & & $\begin{array}{c}0.704 * * * \\
(11.47)\end{array}$ \\
\hline Signed & $\begin{array}{c}1.174 * * * * \\
(6.34)\end{array}$ & $\begin{array}{c}1.162 * * * \\
(6.18)\end{array}$ & & & & $\begin{array}{c}1.177 * * * \\
(7.14)\end{array}$ \\
\hline$\underline{\text { Condition index }}$ & $\begin{array}{c}0.472 * * * \\
(10.40)\end{array}$ & $\begin{array}{c}0.491 * * * \\
(11.89)\end{array}$ & no & no & no & no \\
\hline R-squared & 0.78 & 0.80 & 0.51 & 0.60 & 0.72 & 0.76 \\
\hline
\end{tabular}


Table A1: Standard and corrected rare book price indices and returns

\begin{tabular}{|c|c|c|c|c|c|c|c|}
\hline & coefficient & SD & $\begin{array}{l}\text { estimated } \\
\text { variance of } \\
\text { residuals }\end{array}$ & $\begin{array}{c}\text { standard } \\
\text { index }\end{array}$ & $\begin{array}{l}\text { standard } \\
\text { return \% }\end{array}$ & $\begin{array}{l}\text { corrected } \\
\text { index }\end{array}$ & $\begin{array}{c}\text { corrected } \\
\text { return \% }\end{array}$ \\
\hline 1975 & & & 0.42 & 100 & & 100 & \\
\hline 1976 & -0.07 & 0.16 & 0.78 & 93.61 & -6.39 & 102.07 & 2.07 \\
\hline 1977 & -0.07 & 0.16 & 0.63 & 93.53 & -0.09 & 91.49 & -10.37 \\
\hline 1978 & 0.25 & 0.17 & 0.77 & 128.97 & 37.9 & 139.24 & 52.2 \\
\hline 1979 & 0.34 & 0.17 & 0.66 & 140.75 & 9.14 & 140.78 & 1.11 \\
\hline 1980 & 0.39 & 0.18 & 0.79 & 147.61 & 4.88 & 162.38 & 15.34 \\
\hline 1981 & 0.36 & 0.16 & 0.7 & 143.09 & -3.06 & 147.26 & -9.31 \\
\hline 1982 & 0.46 & 0.16 & 0.66 & 157.75 & 10.25 & 157.58 & 7.01 \\
\hline 1983 & 0.64 & 0.18 & 0.6 & 189.07 & 19.85 & 182.34 & 15.71 \\
\hline 1984 & 0.52 & 0.16 & 0.8 & 168.27 & -11 & 186.09 & 2.06 \\
\hline 1985 & 0.76 & 0.17 & 0.74 & 214.33 & 27.37 & 226.98 & 21.97 \\
\hline 1986 & 0.81 & 0.16 & 0.65 & 225.62 & 5.27 & 223.77 & -1.41 \\
\hline 1987 & 0.89 & 0.19 & 0.59 & 243.8 & 8.06 & 232.92 & 4.09 \\
\hline 1988 & 1.15 & 0.17 & 0.76 & 316.97 & 30.01 & 340.44 & 46.16 \\
\hline 1989 & 1.36 & 0.17 & 0.76 & 388.31 & 22.51 & 416.69 & 22.4 \\
\hline 1990 & 1.68 & 0.16 & 0.73 & 535.54 & 37.92 & 562.57 & 35.01 \\
\hline 1991 & 1.44 & 0.16 & 0.92 & 421.61 & -21.27 & 519.91 & -7.58 \\
\hline 1992 & 1.53 & 0.16 & 0.83 & 462.42 & 9.68 & 524.96 & 0.97 \\
\hline 1993 & 1.58 & 0.16 & 0.68 & 484.11 & 4.69 & 491.25 & -6.42 \\
\hline 1994 & 1.55 & 0.16 & 0.73 & 469.06 & -3.11 & 491.41 & 0.03 \\
\hline 1995 & 1.58 & 0.16 & 0.73 & 486.04 & 3.62 & 509.66 & 3.71 \\
\hline 1996 & 1.73 & 0.16 & 0.83 & 564.22 & 16.09 & 640.15 & 25.6 \\
\hline 1997 & 1.85 & 0.17 & 0.61 & 636.67 & 12.84 & 616.43 & -3.71 \\
\hline 1998 & 1.92 & 0.17 & 0.77 & 684.37 & 7.49 & 742.07 & 20.38 \\
\hline 1999 & 2.11 & 0.17 & 0.7 & 826.93 & 20.83 & 851.25 & 14.71 \\
\hline 2000 & 2.15 & 0.17 & 0.82 & 855.55 & 3.46 & 962.77 & 13.1 \\
\hline 2001 & 2.18 & 0.16 & 0.86 & 883.36 & 3.25 & 1025.78 & 6.54 \\
\hline 2002 & 2.15 & 0.17 & 0.72 & 857.68 & -2.91 & 895.97 & -12.66 \\
\hline 2003 & 2.39 & 0.17 & 0.82 & 1095.62 & 27.74 & 1230.83 & 37.37 \\
\hline 2004 & 2.23 & 0.16 & 0.89 & 929.29 & -15.18 & 1114.64 & -9.44 \\
\hline 2005 & 2.28 & 0.16 & 0.87 & 979.17 & 5.37 & 1149.15 & 3.1 \\
\hline 2006 & 2.59 & 0.17 & 0.73 & 1339.19 & 36.77 & 1403.65 & 22.15 \\
\hline 2007 & 2.69 & 0.16 & 0.8 & 1476.57 & 10.26 & 1629.62 & 16.1 \\
\hline 2008 & 2.57 & 0.17 & 0.71 & 1303.78 & -11.7 & 1354.13 & -16.91 \\
\hline 2009 & 2.21 & 0.16 & 0.7 & 912.82 & -29.99 & 940.66 & -30.53 \\
\hline 2010 & 2.5 & 0.17 & 0.87 & 1222.57 & 33.93 & 1433.26 & 52.37 \\
\hline 2011 & 2.42 & 0.17 & 0.9 & 1125.82 & -7.91 & 1357.93 & -5.26 \\
\hline 2012 & 2.38 & 0.17 & 0.85 & 1083.58 & -3.75 & 1250.75 & -7.89 \\
\hline 2013 & 2.26 & 0.16 & 0.82 & 960 & -11.4 & 1078.07 & -13.81 \\
\hline 2014 & 2.46 & 0.17 & 0.95 & 1164.73 & 21.33 & 1477.9 & 37.09 \\
\hline 2015 & 2.72 & 0.18 & 0.78 & 1519.15 & 30.43 & 1657.55 & 12.16 \\
\hline 2016 & 2.3 & 0.18 & 0.89 & 1001.14 & -34.1 & 1200.74 & -27.56 \\
\hline 2017 & 2.37 & 0.2 & 0.72 & 1069.25 & 6.8 & 1111.54 & -7.43 \\
\hline 2018 & 2.47 & 0.19 & 0.8 & 1186.03 & 10.92 & 1318.94 & 18.66 \\
\hline
\end{tabular}


Table A2: Nationality of authors and location of auction sale

\begin{tabular}{|c|c|c|c|c|}
\hline & UK authors & US authors & other authors & \\
\hline UK auction house & $24.69 \%$ & $2.32 \%$ & $4.97 \%$ & $32 \%$ \\
& $(43 \%)$ & $(7.5 \%)$ & $(42 \%)$ & \\
\hline US auction house & $32.77 \%$ & $28.51 \%$ & $6.73 \%$ & $68 \%$ \\
& $(57 \%)$ & $(92.5 \%)$ & $(58 \%)$ & \\
\hline & $57.5 \%$ & $30.8 \%$ & $11.7 \%$ & $100 \%$ \\
& $(100 \%)$ & $(100 \%)$ & $(100 \%)$ & \\
\hline
\end{tabular}




\section{References}

Aizenman, J. and K. Kletzer (2011). The Life Cycle of Scholars and Papers in Economics: The 'Citation Death Tax'. Applied Economics 43(27): 4135-48.

Ashenfelter, O., O. Gergaud, K. Storchmann and W. Ziemba (2018). Handbook of the economics of wine, Volumes 1 and 2. World Scientific, Singapore.

Burton, B. and J. Jacobsen (1999). Measuring returns on investments in collectibles. Journal of Economic Perspectives 13(4), 193-212.

Burton, B. and J. Jacobsen (2001). The rate of return on investment in wine. Economic Inquiry 39(3), 337-350.

Canoy, M., J. van Ours and F. van der Ploeg (2006). The economics of books. In: V. Ginsburg and D. Throsby (eds.): Handbook of the economics of art and culture, Chapter 21, North Holland, Amsterdam.

Charlin, V. and A. Cifuentes (2014). An Investor-oriented metric for the art market. Journal of Alternative Investments 17(1), 87-101.

Dimson, E. and C. Spaenjers (2011). Ex post: The investment performance of collectible stamps. Journal of Financial Economics 100(2), 443-458.

Fadiman, C. (1960). The lifetime reading plan. World Publishing, Cleveland and New York.

Faye, B. and E. Le Fur (2019). On the constancy of hedonic wine price coefficients over time. Journal of Wine Economics 14(2), 182-207.

Ginsburg, V., J. Meio and M. Moses (2006). The computation of price indices. In: V. Ginsburg and D. Throsby (eds.): Handbook of the economics of art and culture, chapter 27, North Holland, Amsterdam.

Girard, R. (1961). Mensonge romantique et vérité romanesque. Grasset, Paris. (English translation: Deceit, Desire and the Novel, Johns Hopkins Press, Baltimore, 1966.)

Goetzmann, W., L. Renneboog and C. Spaenjers (2011). Art as Money. American Economic Review, Papers and Proceedings 101(3), 222-226.

Hillman, A.L. (2010). Expressive behavior in economics and politics. European Journal of Political Economy 26(4), 403-418.

Kells, Stuart (2003). Rare book auction data in Australia. Australian Economic Review 36(4), 435-41.

Laurs, D. and L. Renneboog (2019). My kingdom for a horse (or a classic car). Journal of International Financial Markets, Institutions and Money 58, 184-207.

Le Fur, E. and J. Outreville (2019). Fine wine returns: a review of the literature. Journal of Asset Management 20, 196-214. 
Mandel, B. (2009). Art as an Investment and Conspicuous Consumption Good. American Economic Review 99(4), 1653-1663.

Martin, S. (2018). Driving Returns: Determinants of the Returns Associated with Collectible Automobiles. Journal of Wealth Management 21(1), 110-123.

Pesando, J. and P. Shum (2007). The law of one price, noise and "irrational exuberance": the auction market for Picasso prints. Journal of Cultural Economics 31(4), 263-277

Pesando, J. and P. Shum (2008). THE AUCTION MARKET FOR MODERN PRINTS: CONFIRMATIONS, CONTRADICTIONS, AND NEW PUZZLES. Economic Inquiry 46(2), 149-159.

Pownall, R.; S. Satchell and N. Srivastada (2019). A random walk through Mayfair: Art as a luxury good and evidence from dynamic models. Journal of International Money and Finance 95, 112-127.

Raven, J. (2013). Debating Bibliomania and the Collection of Books in the Eighteenth Century. Library \& Information History 29(3), 196-209.

Renneboog, L. and C. Spaenjers (2012). Hard assets: The returns on rare diamonds and gems. Finance Research Letters 9(4), 220-230.

Renneboog, L. and C. Spaenjers (2013). Buying beauty: On prices and returns in the art market. Management Science 59, 36-53.

Satchell, S. and J Auld (2009). Collecting and Investing in Stamps. In S. Satchell (ed.): Collectible investments for the high net worth investor, Chapter 10, Academic Press, Cambridge (Mass.)

SCOTT, F. and YELOWITZ, A. (2010). PRICING ANOMALIES IN THE MARKET FOR DIAMONDS: EVIDENCE OF CONFORMIST BEHAVIOR. Economic Inquiry 48, 353-368.

Slote, S. (2004). Ulysses in the plural: The variable editions. The National Library of Ireland Joyce Studies. Dublin.

https://www.academia.edu/2531525/Ulysses in the Plural The Variable Editions of Joyc es Novel

Stigler, G. and G. Becker (1977). De gustibus non est disputandum. American Economic Review 67(2), 76-90.

Ursprung, H. and C. Wiermann (2011). Reputation, price and death: An empirical analysis of art price formation, Economic Inquiry 49, 697-715.

Vecco, M. and R. Zanoly (2017). Don't let the easy be the enemy of the good. Returns from art investments: What is wrong with it? Journal of Economic Behavior and Organization 140, 120129.

Wyburn, J. and P. Roach (2012). An hedonic analysis of American collectable comic-book prices. Journal of Cultural Economics 36, 309-326. 


\section{Exhibits}

\section{ULYSSES suppressed four} times during serial publication in "The Little Review" will be published by "SHAKESPEARE AND COMPANY" complete as written.

This edition is private and will be limited to 1.000 copies :

roo copies signed on Dutch hand made paper. . . . . $350 \mathrm{fr}$ I go copies on vergé d'Arches. . . . . . . . $250 \mathrm{fr}$. 750 copies on hand made paper. . . . . . . . $150 \mathrm{fr}$.

The work will be a volume in- 80 croun of $\$ 00$ pages.

Subscribers will be notified when the volume appears, which will be sent to them by registered post immediately on receipt of payment.

All correspondence, cheques, money-orders should be addressed to :

MISS SYLVIA BEACH

"SHAKESPEARE AND COMPANY"

12, RUE DE L'ODÉON, PARIS - VI=

Exhibit 1: Subscription announcement by Shakespeare and Company 


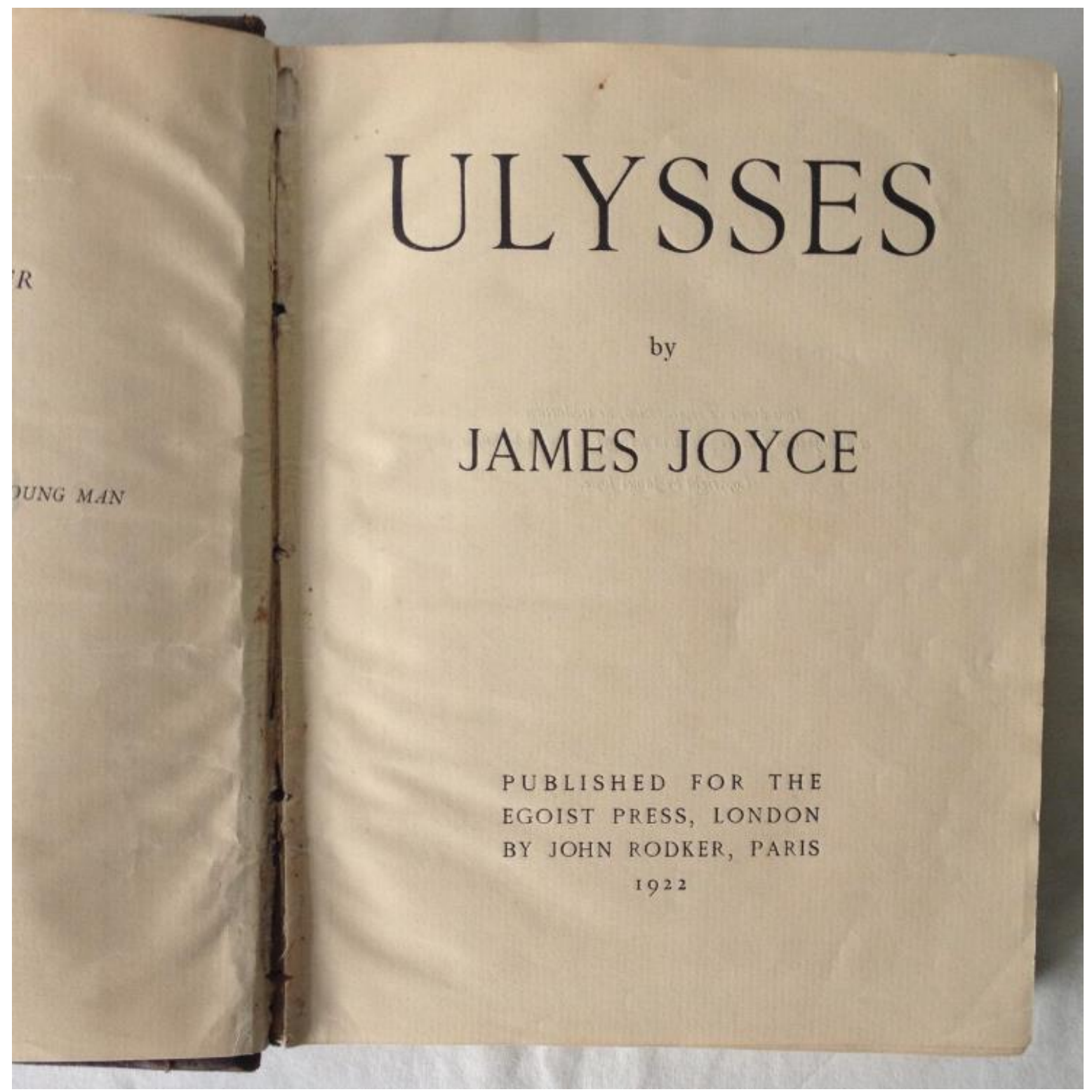

Exhibit 2: The second printing of Ulysses 


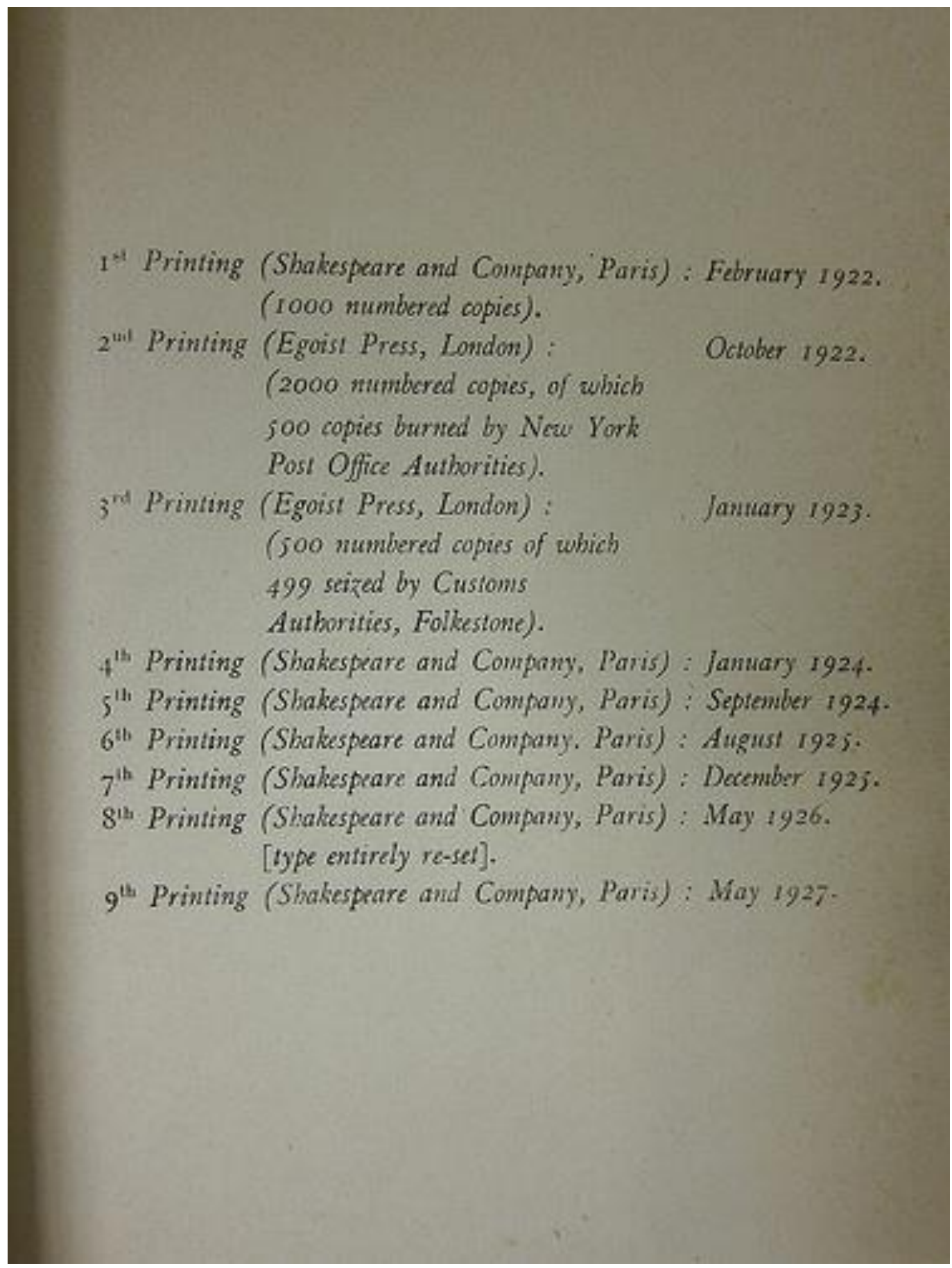

Exhibit 3: Edition statement from the Shakespeare and Company second edition 
Joyce, James, 1882-1941

- Ulysses.

Paris, 1922

one of 750 on handmade paper

4to,

Half mor

1st Ed

Tp, half-title \& portion of p. 92/92 supplied in facsimile. Sold w.a.f

Christie's East, Dec 12, 2000, lot 289, \$800

Slocum \& Cahoon A17. Edition is 100 on Dutch handmade paper; 150 on verge d'Arches; and 750 on handmade paper

Joyce, James, 1882-1941

- Ulysses.

Paris, 1922

one of 750 on handmade paper

4to,

orig wraps

minor wear along bottom edge of spine, short repairs at corners of upper spine edge

1st Ed

Christie's East, Apr 12, 2000, lot 112, \$26,000

Slocum \& Cahoon A17. Edition is 100 on Dutch handmade paper; 150 on verge d'Arches; and 750 on handmade paper

\section{Exhibit 4}




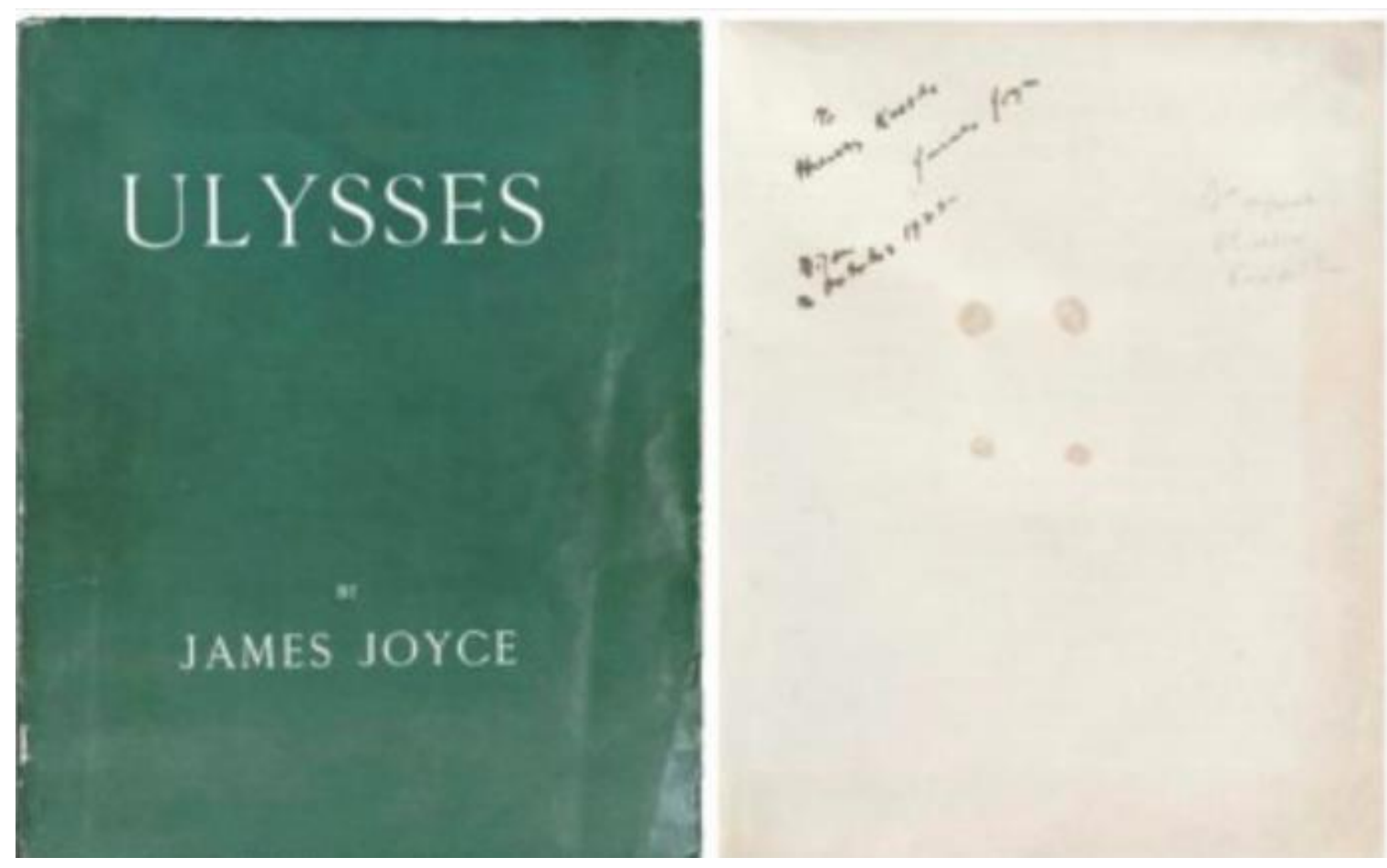

\section{Exhibit 5}

https://www.christies.com/lotfinder/Lot/joyce-james-ulysses-paris-shakespeare-andcompany-3984062-details.aspx

FIRST EDITION, LIMITED ISSUE, ONE OF 100 COPIES ON DUTCH HANDMADE PAPER, this copy out-of-series and unsigned on the limitation page. PRESENTATION COPY, INSCRIBED BY JOYCE TO HENRY KAESER on the front flyleaf: "To Henry Kaeser James Joyce Dijon 12 October 1922."

Henry Kaeser was a publisher in Lausanne and for a time in Paris. 12 October was the date of the second printing of Ulysses (The Egoist Press edition) and Joyce was in Dijon at the time to see the printer of the Shakespeare and Company first edition, Maurice Darantière. On his way from Paris to Nice, Joyce made the stop and inscribed a copy of the one of 150 issue to Darantière and this copy to Kaeser, who was also there visiting. The Darantière copy is now in the Rosenbach Museum, having been acquired at the John Quinn sale in 1924. That copy is marked "reservé" in an unknown hand on the colophon leaf, indicating that it was the printer's retained copy. The present copy, on the rarer Dutch handmade paper, is also unnumbered and unsigned, suggesting it was another of Darantière's retained copies.

PRESENTATION COPIES OF THIS ISSUE ARE VERY SCARCE. In J. Howard Woolmer's census, only nine copies, of the toal 59 located, have presentation inscriptions from Joyce. Of these nine, seven are in institutional libraries. THIS AND THE COPY INSCRIBED TO MARGARET ANDERSON ARE THE ONLY TWO INSCRIBED COPIES STILL IN PRIVATE HANDS. The Anderson copy was sold in the James Gilvarry Collection, Christie's New York, 7 February 1986, lot 362. This is the only unnumbered copy on Dutch handmade paper noted by Woolmer in his census. Slocum \& Cahoon do not mention out-of-series copies. See "Ulysses" at Auction with a Preliminary Census(reproduced from the James Joyce Quarterly, Vol. 17, No.2, Winter 1980). Connolly, The Modern Movement 42; Slocum \& Cahoon A17. 
(ii) VLADIMIR NABOKOV

Among Vladimir Nabokov's 'desultory memories' of his years at Cambridge, when he knew Joyce's future son-in-law not to be (Paul Léon's brother-in-law Alex Ponisovsky), and during which he was lectured on things Slavonic by an Irishman named Alexander Goudy, there is one memory, we are told, of 'P.M. [a fellow student named Peter Mrosovskyl storming into my room with a copy of Ulysses freshly smuggled from Paris'; he did not read the book through himself until 'fifteen years later' when he 'liked it enormously'. ${ }^{6}$ Mrosovsky 'stomped up and down my digs' with his fresh blue copy of Ulysses as he regaled Nabokov with 'one or two spicy passages from Molly's monologue' (Nabokov, 1974, p. 103).

Source: Neil Cornwell: James Joyce and the Russians, MacMillan, London, 1992 (p. 71)

\section{Exhibit 6}



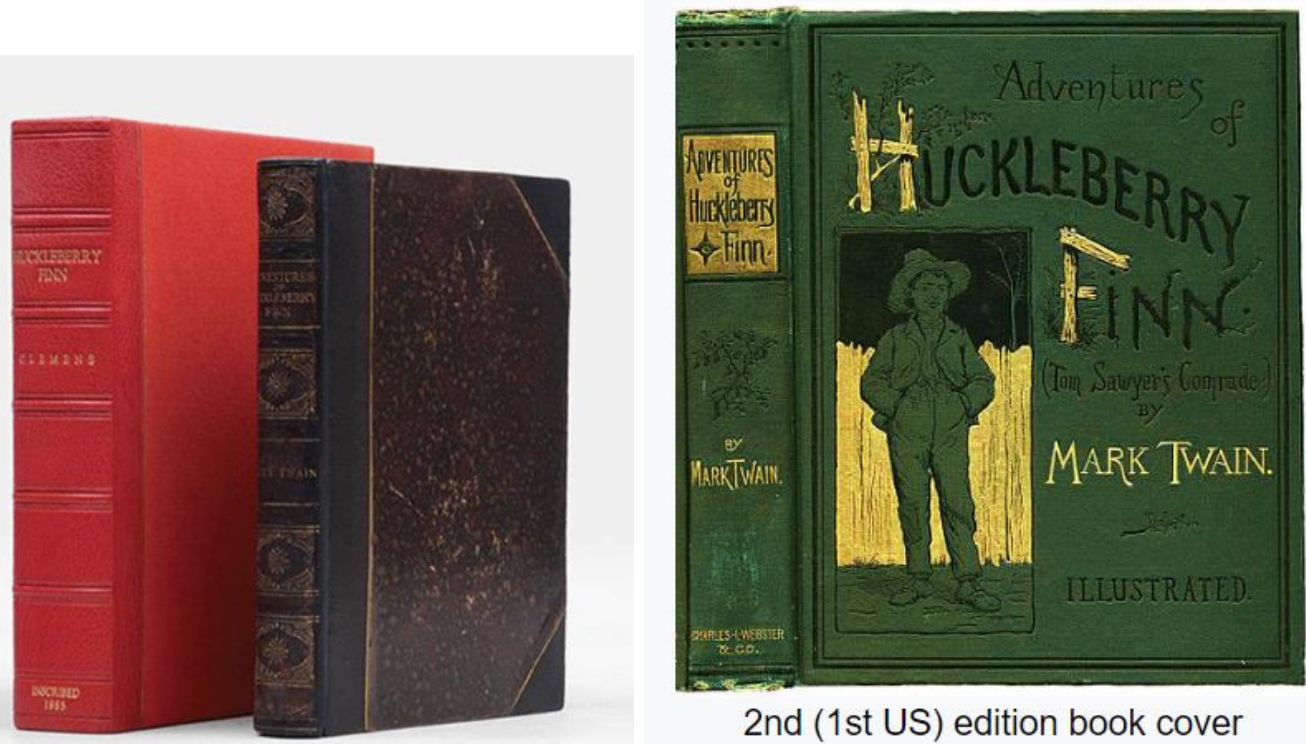

2nd (1st US) edition book cover
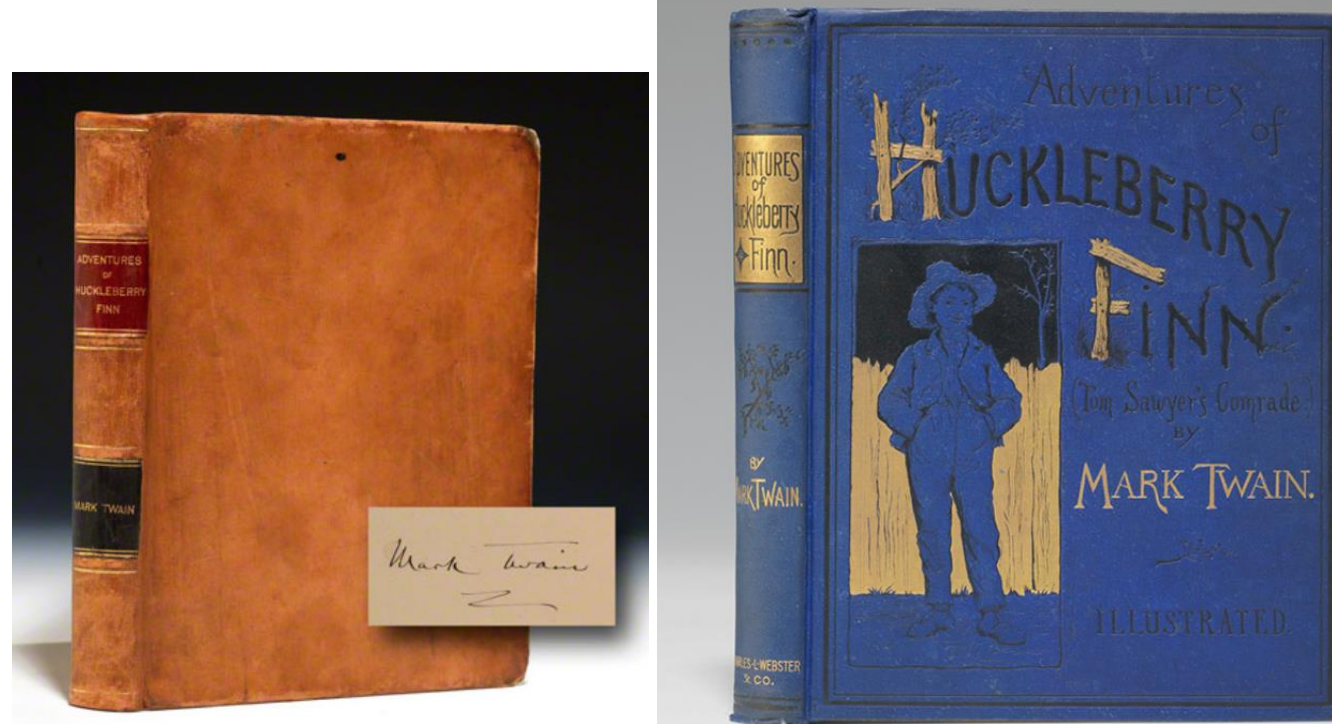

\section{Exhibit 7}




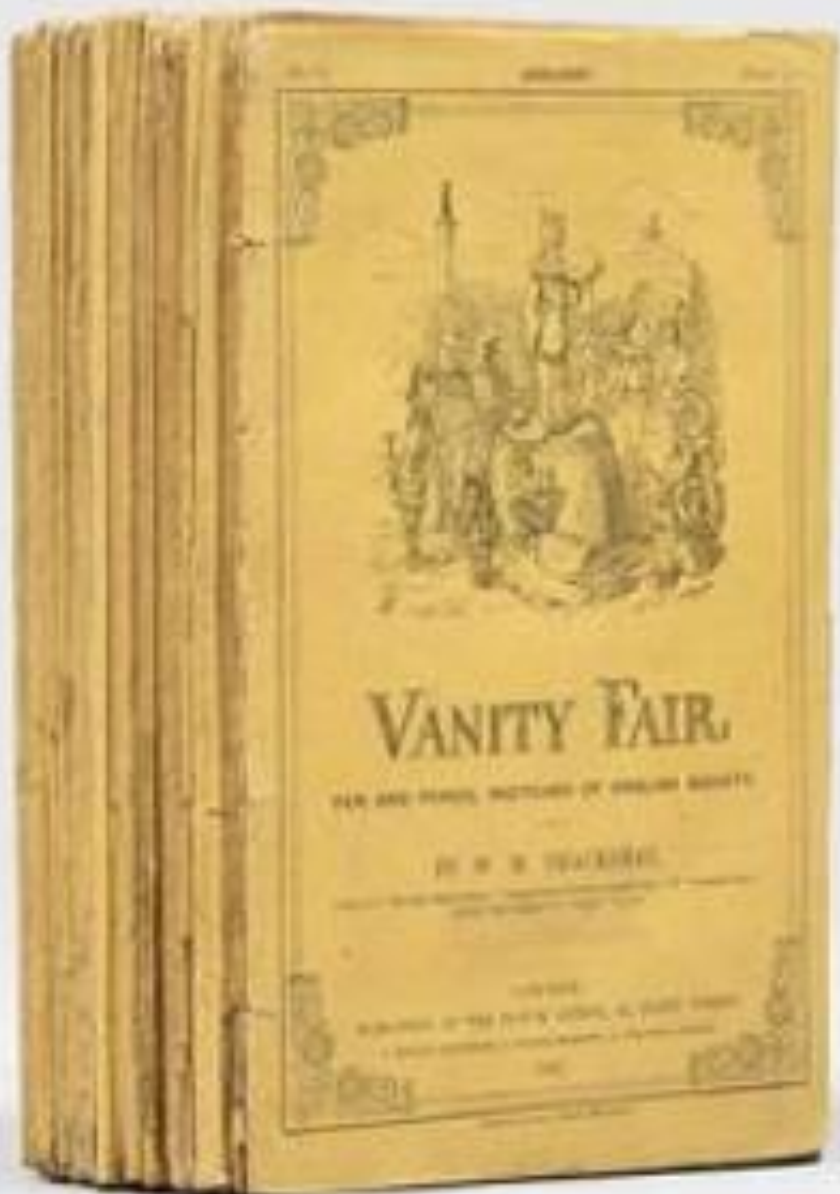

Exhibit 8 